\title{
Ketubbot en-cubiertas: fuentes para el estudio del matrimonio judío en Jaca y los Almosnino *
}

\author{
Javier Castaño $^{* *}$ \\ ILC - CSIC, Madrid
}

Edición y estudio de varios fragmentos de ketubbot de Jaca de la segunda mitad del siglo XV, en las que diversos miembros de la familia Almosnino aparecen mencionados, bien como contrayentes, bien como testigos (y/o escribanos). La lectura de estos textos y el análisis combinado de su estructura formal, contenido temático y soporte material, es un punto de partida para analizar distintos aspectos de la vida de los individuos y de la comunidad judía.

Palabras CLAVE: ketubbot; prosopografía; mujeres judías; Aragón; siglo XV; escribanos judíos.

Ketubbot en-cubiertas: Sources for the Study of the Jewish Marriage in Jaca and the ALMOSNINO.-Edition and analysis of four 15th-century fragmentary ketubbot from Jaca (Aragon), in which are mentioned several members of the Almosnino family, either as bridegrooms or witnesses/scribes. A close reading of these texts, paired with the analysis of their formal structure and contents, is a starting point for the analysis of divers aspects of the life of individuals and their community.

KeYwords: Ketubbot; Prosopography; Jewish Women; Aragon; $15^{\text {th }}$ Century; Communal Scribes.

Desde fines del siglo XIX se han venido sucediendo hallazgos de textos documentales hebraicos medievales en diversos archivos aragoneses, principalmente, pero no sólo, dentro de encuadernaciones y cubiertas de protocolos notariales. Este fenómeno, que no es exclusivo de Aragón, ha llamado la atención de estudiosos, tanto dentro como fuera ' del país.

Uno de los primeros fragmentos aragoneses cuyo descubrimiento quedara registrado se relaciona con la aparición en 1884 de los manuscritos árabes y arábigo-

"Este artículo forma parte de un estudio documental más amplio en preparación, en complemento de la obra de J. L. LACAVE, Medieval Ketubbot from Sefarad (Jerusalem 2002).

** javier.castano@cchs.csic.es

${ }^{1}$ Así, S. Assaf, «Kerikat sefarim», Sinai, año 1 (5697/1937), págs. 505-510, reimpr. en su Be-ohalé Ya'acob. Peraquim me-ḥayyé ha-tarbut šel ha-yehudim bi-yemé ha-benáyim (Jerusalem 5703/1942-43), págs. 20-26. 
aljamiados de Almonacid de la Sierra (Zaragoza). Tras ser adquiridos parte de los manuscritos en 1910 por la Junta de Ampliación de Estudios, estos pasaron a engrosar los fondos de su biblioteca. En efecto, dentro de las cubiertas de un manuscrito fragmentario del Corán (s. XVI) habían aparecido tres folios de un cuaderno de cuentas, catalogadas como escritura «en aljamiado rabínico, dialecto aragonés, siglo XV (?); contienen cuenta de los gastos comunes de una judería, quizá la de Daroca ${ }^{2}$. Cuando en 1912 se publicó el catálogo de manuscritos realizado bajo la dirección de Ribera y Asín, los tres folios se hallaban en la colección de manuscritos árabes y aljamiados de la biblioteca de la Junta de Ampliación de Estudios ${ }^{3}$.

No es mi intención ahora realizar un repaso de estos hallazgos, sino hacer una llamada de atención acerca de la necesidad de editar y estudiar sistemáticamente estos documentos, con frecuencia, fragmentarios, de importancia para la historia y la filología.

Buena parte de las treinta y dos ketubbot editadas por José L. Lacave en su edición y estudio -desafortunadamente póstumos-, se ocultaban originalmente en cubiertas de registros manuscritos y libros impresos. La aparición de fragmentos de cuatro nuevas ketubbot de Jaca datadas en la segunda mitad del siglo $\mathrm{XV}$ permite conocer mejor su estructura, ya que hasta ahora solo contábamos con el estudio de una ketubbá de 1428 realizado por Lacave ${ }^{4}$.

La publicación de estos documentos puede permitir a los estudiosos indagar en cuestiones relativas a valores sociales y estrategias familiares, relaciones de género, movilidad demográfica, etc. Mi intención aquí es estudiar esos cuatro fragmentos de ketubbot (Jaca 2-5) ${ }^{5}$, a los que he sumado otros dos documentos (Apéndice a-b) relativos a Sos, que fueron redactados por escribanos de la familia Almosnino de Jaca mencionados en las ketubbot en calidad de contrayentes o de testigos.

\footnotetext{
${ }^{2}$ Habían aparecido dentro de las cubiertas del manuscrito n. ${ }^{\circ}$ xxxiv. Cf. J. RiBera y M. Asín, Manuscritos árabes y aljamiados de la biblioteca de la Junta. Noticia y extractos por los alumnos de la sección de árabe (Madrid 1912), pág. 251. La lám. 18 reproduce fotografía del f.o 3b (identificado erróneamente como «Documento aljamiado rabínico de la judería de Daroca»).

${ }^{3}$ En la actualidad, dichas cuentas forman parte de la colección [A. Sh.] Yahuda (National Library of Israel). Una edición con estudio preliminar apareció publicada en Sef 64 (2004), págs. 315-340.

${ }^{4}$ J. L. LaCaVE, «Una ketubba de Jaca», Sef 52 (1992), págs. 421-428.

${ }^{5}$ En diciembre de 2002, la directora del Archivo Histórico Provincial de Huesca [= AHPH], María Rivas, me envió la imagen de diversos documentos y fragmentos en escritura hebrea entre los que se encontraban estas cuatro ketubbot, que habían aparecido entre 1985-1992 en las cubiertas de varios protocolos notariales con motivo de su revisión para microfilmación. En 2003 remití al archivo la identificación de los fragmentos para su catalogación. La imagen de dos de estas ketubbot (las menos interesantes desde el punto de vista del contenido) fue usada para ilustrar alguna publicación aprovechando su estética singular (concretamente, Jaca 3 y 4).
} 
Este estudio está en la línea y pretende complementar trabajos previos de otros investigadores como J. L. Lacave y, en cierta manera, también David Romano que ya en 1982 planteaba la necesidad de iniciar un estudio serio de la aljama judía de Jaca, para el que él contribuía con un detallado análisis de su demografía en $1377^{6}$. Familias como los Abengoyós y los Abanbrón destacaban dentro de la oligarquía local, en la que se incluía también alguna rama de las familias Almosnino y Alcalá. Con posterioridad, han visto la luz otros estudios, entre ellos, uno de Jean Passini, en donde se intenta precisar la topografía de la judería de Jaca y de sus sinagogas, corrigiendo afirmaciones que se habían venido manteniendo en la tradición local ${ }^{\top}$. Finalmente, otros trabajos han aumentado sustancialmente el volumen de información con el que contamos acerca de esta aljama, gracias a la consulta de la documentación de protocolos notariales del siglo $\mathrm{XV}^{8}$.

\section{Los Almosnino de Jaca}

Una familia particularmente destacada en la aljama de Jaca era la de los Almosnino, varios de cuyos miembros están documentados en la ciudad desde, al menos, fines del siglo XIII ${ }^{9}$, no solamente por la documentación romance, sino también por las fuentes hebreas ${ }^{10}$. No pretendo aquí trazar una genealogía de las distintas ramas de esta familia, extendida a Huesca en el siglo XV, alguno de cuyos descendientes judíos conserva una posición relevante después

${ }^{6}$ D. Romano, «Prorrata de contribuyentes judíos de Jaca en 1377», Sef 42 (1982), págs. 3-39.

${ }^{7}$ J. PAssinI, «La juderia de Jaca», en Minorités et marginaux en France méridionale et dans la péninsule Iberique (VII - XVIII ${ }^{e}$ siècles). Actes du Colloque de Pau, 27-29 mai 1984 (Paris 1986), págs. 143-155.

${ }^{8}$ M. A. Motis Dolader, La aljama judía de Jaca en el siglo XV (Huesca 1998), prolijo estudio lleno de datos necesitados de elaboración. Es importante el documento estudiado en E. GUTwIRTH \& M. A. Motis Dolader, «Twenty-Six Jewish Libraries from Fifteenth-Century Spain», The Library 18 (1996), págs. 27-53.

${ }^{9}$ Una de las primeras referencias es la relativa a Berzelay Albuxnino que, junto con Vidal Elnieto, actúa como procurador de la aljama en 1284-85, cf. J. RÉGNÉ, History of the Jews in Aragon. Regesta and Documents, 1213-1327 (Jerusalem 1978), n. 1277 (cf. también n. ${ }^{\circ} 2788,2795$ y 2517).

${ }^{10}$ Entre ellos, el responsum de R. Šelomó b. Adret (I, 1179) relativo a la hija de R. Ișhac Almosnino de Jaca y las consultas realizadas por R. Šemuel Almosnino a R. Ișḥac Perfet (n. ${ }^{\circ}$ 455-456 y 470), disponibles en traducción en M. A. Motis y E. Gutwirth, «La aljama judía de Jaca en la época de la disputa de Tortosa (1410-1420)», Anuario de Estudios Medievales 26 (1996), págs. 221-327: 322-323 y 325-327. Quizás pueda identificarse a R. Šemuel Almosnino con el homónimo y coetáneo autor de un supercomentario a Raší, cf. Y. M. Toledano, Apiryon (Jerusalem 5665 [1904]), págs. 14b-25a. 
de $1492^{11}$. Mi interés viene determinado por la mención en las ketubbot que estudio más adelante a diversos miembros de una misma rama de la familia, bien en calidad de testigos (y/o escribanos), o bien en calidad de contrayentes de esponsales.

La presencia de los Almosnino en la escribanía de la aljama es anterior al periodo que me interesa. De hecho, durante las décadas centrales del siglo XIV, un miembro de esta familia, Mahir Almosnino, había recibido del rey aragonés el cargo vitalicio de rabino y «scriptoris judeorum» de la aljama de Jaca ${ }^{12}$, que desempeñará hasta su muerte.

Pese a la fluctuación existente en la nomenclatura (que habla alternativamente de escribanos y de notarios judíos), salvo que mediara una autorización real, los escribanos judíos eran personas privadas, carentes de autoridad para redactar documentos públicos, pues las aljamas en sí no estaban capacitadas para conferirles la categoría de notarios ${ }^{13}$. Más adelante se incluyen diversos tipos de documentos redactados por estos individuos, que incluyen contratos matrimoniales, cartas de donación y cartas de procuración, y en los que aparecen en calidad de testigos ${ }^{14}$.

${ }^{11}$ De hecho, Mošé b. Baruj Almosnino estaba vinculado a esta familia por vía paterna y por la materna, como él mismo señala en su obra homilética Meammeṣ kóạ̣ (Venecia 1588 [reprod. 1969], pág. 97a), donde menciona a uno de sus bisabuelos maternos, don Abraham Almosnino, del cual dice que, en compañía de sus hijos maestre Yosef y don Ḥayyim, sufrió martirio. Acerca de Abraham Almosnino entre 1473 y 1478, sucesivamente «notario» de la aljama de Huesca, contador de la mano mediana y baja, adelantado de la mano mayor y «almosnero», cf. E. BENEDICTO Gracia, «Documentos acerca del funcionamiento del sistema de insaculación en la aljama judía de Huesca (siglo XV)», Sef 66 (2006), págs. 309-344: 319-323.

${ }^{12}$ La carta de nombramiento (fechada en 2-VIII-1339) fue publicada por J. RIERA I SANS, Els poders públics i les sinagogues. Segles XIII-XV (Girona 2006), doc. 104, págs. 309-310. En 1375 su vacante es ocupada por Bitas Abingoyós tras recibir el nombramiento real, ibíd, doc. 192, págs. 382-383.

${ }^{13}$ El asunto fue expuesto de forma sumaria en J. RIERA I SANS, «Notaris jueus i sarraïns», en A. MARTínez SARrión (dir.), Estudios históricos y documentos de los archivos de protocolos 4 (1974) [= Miscelánea en honor de Raimundo Noguera de Guzmán], págs. 434-438 y 444445. Con posterioridad trató el tema A. Blasco Martínez, «Notarios-escribanos judíos de Aragón», en Rashi 1040-1090. Hommage à Ephrä̈m E. Urbach..., ed. G. SED-RAJNA (Paris), págs. 645-656. Recientemente, se han realizado valiosas consideraciones que permiten subsanar algunos enfoques descuidados del problema, cf. J. RIERA I SANS, «Esculls en la història dels jueus», Afers 53/54 (2006), págs.137-160: 144-146.

${ }^{14}$ La cercana aljama de Huesca incluía el cargo de «notario» (léase, escribano), entre la nómina de cargos «electos» anuales mediante el sistema de insaculación. Entre 1471-1478 se suceden cuatro individuos en ese cargo, cf. BenEDicto Gracia, «Documentos acerca del funcionamiento del sistema de insaculación», 317-324. 
Los documentos que estudio ahora nos permiten conocer tres generaciones de individuos pertenecientes a la familia Almosnino, alguno de los cuales actúa como escribano judío de Jaca durante las décadas centrales del siglo XV:

1. Zerahyá B. Jacob Almosnino: firma como testigo la ketubbá de 1429 (Jaca 1). De la información publicada no he logrado averiguar ninguna otra referencia documental a é $1^{15}$. Es incierta la identidad de su padre Jacob, pues aunque encontramos en 1419 una mención a Jacob Almosnino como «sanoguero» de la sinagoga de Jaca ${ }^{16}$, puede tratarse de un homónimo.

2. JACOB B. ZeRAHYÁ Almosnino: si tuviéramos que juzgar por la onomástica, concluiríamos que se trata de un hijo del anterior. Su firma aparece al final de la parte adicional de la ketubbá de Raḥel Sarfatí en 1462 (Jaca 2). Como la firma de Jacob está trazada por la mano que escribe la ketubbá, podemos deducir que, a la vez que testigo, actúa de escribano. En 1467, el mismo Jacob redacta la carta de autorización y procuración que Hayyim Alcastiel otorga en Jaca a su cuñado David Maçó (Apéndice b). Su firma aparece al final de esa escritura. En este documento, el nombre de su padre Zerahyá viene acompañado de la fórmula habitual empleada para los fallecidos (ע')).

3. Desconozco el grado de parentesco de Don Bonafós b. Yosef Almosnino con los anteriores, pero sí es posible identificar al novio de la ketubbá de 1462 (Jaca 2) con el escribano que redacta y firma una carta de donación anterior a esa fecha (Apéndice a). En la ketubbá de matrimonio de Bonafós, el nombre de su padre aparece acompañado de la fórmula de aplicación habitual a los fallecidos (J"). Por el contrario, en la carta de donación mencionada la fórmula usada es la que se aplica en vida a los estudiosos de la Torá (נר"ו). En consecuencia, su participación en la carta de donación habría sido anterior a su propia ketubbá. Eso hace de Bonafós un coetáneo de Jacob b. Zerahyyá (2). Las casas que entrega a su mujer en la donación de la ketubbá se localizaban en las inmediaciones de la sinagoga de Jaca. Además, le entregaba la propiedad de un asiento sinagogal. El hecho de que la ketubbá hubiera sido reciclada ya en 1479 -o antes-, siendo utilizada para hacer anotaciones notariales que nada tenían que ver con los contrayentes o sus familias, permite suponer que el matrimonio se habría extinguido antes de esa fecha, bien como resultado de la muerte de uno de los cónyuges (o de ambos), del divorcio, o bien de su bautismo. En cualquier caso,

${ }^{15}$ Es bastante significativo que su nombre no aparezca ni una sola vez en esta modalidad en las nóminas de judíos de Jaca o Huesca, pero sí, y repetidamente, el de «Azerián (Almosnín)». No se puede descartar una correspondencia entre ambos nombres, como tampoco un error del notario.

${ }^{16}$ Motis y Gutwirth, «La aljama judía de Jaca», 234-235. 
lo plausible es que hubiera mediado una reclamación ante notario de alguno de los derechos de herencia de Rahel, la mujer de Bonafós, o de sus herederos. Por ello, adquiere significado la mención en la documentación notarial a un Bonafós Almosnino como padre de Johan de Pardiniella, converso reciente en $1481{ }^{17}$.

4. No hay ninguna evidencia directa que demuestre de manera fehaciente que Iș̣ac B. JАCOB Almosnino sea hijo de Jacob b. Zerahyyá (2), más allá de la coincidencia onomástica. Se conserva la ketubbá del matrimonio de Iṣ̣ac con Jamila (Jaca 3) redactada en 1465. Años más tarde, Iṣ̣ac es mencionado como testigo en otra ketubbá realizada en 1489 (Jaca 5), por la que sabemos que su padre Jacob ya había fallecido. Actúa como escribano en diversos pleitos entre judíos de la aljama de Jaca ${ }^{18}$. En 1490 aparece mencionado como uno de los adelantados de la aljama ${ }^{19}$.

Precisamente, los nombres de cuatro de los individuos anteriores, Jacob b. Zerahyyá (2), Yosef, padre de Bonafós (3), Iṣhac b. Jacob (4), y maestre Astruc Almosnino (5) aparecen acompañados de la fórmula de bendición נר"ו, reservada a estudiosos de la Torá. Que sepamos, dos de estos individuos, Jacob b. Zerahyá (2) y Bonafós b. Yosef (3) actúan, al menos, como escribanos. Con ellos hay que incluir a Ișhac b. Jacob (4), del que existe testimonio en documentación notarial de su actuación como escribano en distintos asuntos.

\section{Las Ketubbot de Jaca}

Los datos incluidos en las ketubbot nos ofrecen una valiosa información para el análisis prosopográfico y el conocimiento de las redes sociales, pero también para el estudio de los niveles de riqueza, con detalles acerca de la cuantía de las dotes y la descripción de bienes inmuebles. Desde otra perspectiva, la ketubbá simboliza el inicio de un proyecto familiar pensado para garantizar la continuidad de la vida judía. Paradójicamente, la conservación de numerosas ketubbot recicladas como material de encuadernación de protocolos notariales -lo que explica que pocas se hayan conservado completas-, apunta en algún caso al fracaso de los objetivos familiares planteados inicialmente, como veremos más adelante.

Pasemos primero a ver la estructura de la ketubbá utilizada en Jaca a lo largo del siglo XV, a partir de los escasos testimonios conservados. Fue Lacave, el que a

\footnotetext{
${ }^{17}$ Motis Dolader, La aljama judía de Jaca, 35.

${ }^{18}$ Motis Dolader, La aljama judía de Jaca, 122 y 126, y cf. también págs. 51 (nota 184) y 222.

${ }^{19}$ Motis Dolader, La aljama judía de Jaca, 108.
} 
partir del análisis de una primera ketubbá de 1429 (Jaca 1) llamó la atención acerca de la semejanza de su estructura formal con la que observaba en las ketubbot coetáneas de Tudela. Además de proporcionarnos información complementaria interesante acerca de los judíos de la ciudad, los nuevos fragmentos (datados en 1462 [Jaca 2], 1465 [Jaca 3], 1487 [Jaca 4] y 1489 [Jaca 5]) confirman su impresión inicial, si bien permiten añadir algunas matizaciones, en relación a pequeñas diferencias respecto de las ketubbot de Tudela ${ }^{20}$. En opinión de Lacave, las ketubbot de Tudela y la de Jaca seguían de cerca la pauta del Sefer ha-Šetarot de Yehudá al-Bargeloní en lo concerniente al cuerpo principal ${ }^{21}$.

En líneas generales, una ketubbá está compuesta por un cuerpo principal y una parte adicional, que se distinguen a simple vista por el uso de tipos distintos de letra (cuadrada y cursiva, respectivamente). Disponemos del cuerpo principal, siquiera truncado en alguna de sus partes, de cuatro de las cinco ketubbot (Jaca 1 y 3-5), y tenemos constancia de la presencia de elementos decorativos en dos casos (Jaca 1 y 4 ).

Los textos de Jaca siguen siempre el mismo orden: tras las formalidades iniciales donde se detalla la fecha, lugar e identidad de los contrayentes, sigue la fórmula matrimonial con el móhar (מוהר) o 'principal' de la ketubbá y la toséfet (תוספת) o ‘incremento’ al móhar, añadido al principal de la ketubbá, y en ambos casos, ofrecidos por el novio a la novia. Tras ellos, la valoración -en moneda aragonesa- de la nedunyá (נדוניא) o 'dote', aportada por la familia de la novia en ajuar, alhajas y dinero, aunque sin detallar su contenido. La dote es considerada șon barzel (צאן ברזל, 'rebaño férreo'), lo que se indica expresamente, es decir, son bienes inalienables cuya propiedad, aunque nominalmente permanece en manos de la mujer, está gestionada por el marido con la condición de garantizar la integridad de su devolución en caso de disolución del matrimonio, de manera que si hubiera ganancias o pérdidas, estas quedarían a cargo del marido.

Esas tres cantidades citadas son las que la mujer debería recibir en caso de disolución del matrimonio, y por ello se añade la cláusula de aharayut (אחריות) o 'garantía', por la que el marido se compromete (en primera persona) a que se le pague a ella como acreedora preferente, eligiendo entre sus bienes de mayor

${ }^{20}$ Una exposición detallada de la estructura formularia de las ketubbot de Tudela en comparación con lo ordenado en las ordenanzas de la aljama local, en J. L. LACAVE, «El contrato matrimonial entre los judíos navarros», Estudios Mirandeses 8 (1988), págs. 91-99; que se completa con un análisis esquemático comparativo de las distintas variedades regionales de ketubbot, en ID., «Las leyes matrimoniales en las taqqanot españolas», en Rashi 1040-1090. Hommage à Ephrä̈m E. Urbach..., ed. G. SED-Rajna (Paris), págs. 677-682.

${ }^{21}$ LACAVE, «Las leyes matrimoniales», 679. 
valor. Esta sección finaliza con la firma de, al menos, dos testigos, uno de los cuales es el escribano del documento.

La parte adicional es la que puede tener mayor interés desde un punto de vista informativo. De las cinco ketubbot de Jaca, sólo disponemos de la parte adicional de las tres primeras.

Comienza con la consignación, en forma de contrato de compraventa, de la mattaná le-ḥud (מתנה לחוד), o 'donación aparte', denominada en las ketubbot de Jaca simplemente mattaná (מתנה), 'donación', que, en adición al principal e incremento, hace el novio a la novia ${ }^{22}$. De hecho, en las ketubbot conocidas de Jaca no aparece utilizado ni una sóla vez el término [mattaná] le-ḥud, sino que se habla simplemente de mattaná gemurá ('donación íntegra'), que parece equivaler a aquella ${ }^{23}$. Esta donación consiste fundamentalmente en propiedades inmuebles en posesión del novio en el momento del matrimonio, a veces, de reciente adquisición, y que suelen abarcar la futura vivienda familiar. Por ejemplo, en Jaca 1 se especifica que los bienes incluidos en la donación habían sido recibidos un año antes de la firma de la ketubbá de la madre del novio. Ocasionalmente, la donación puede comprender también bienes rústicos (viñas, etc., como sucede en Tudela), pero también una cantidad de dinero o, como veremos en Jaca 2, la propiedad sobre un asiento sinagogal.

La donación registra un acto jurídico suplementario que se acostumbra a escribir en el mismo pergamino, y aunque su fecha suele coincidir con la de la firma de la ketubbá, no siempre lo hace. En una ketubbá de Borja (1482) la donación aparte (allí sí se denomina así) había quedado registrada por separado en otro pergamino, pues había tenido lugar dos días después de la firma de la ketubbá. Por el contrario, en Jaca 3, se especifica que la donación recogida en la ketubbá había quedado registrada con anterioridad a esta en otro documento, ya que el acto de donación había tenido lugar cinco días antes de la boda, en presencia, eso sí, de los mismos testigos de la ketubbá. Lacave tenía la impresión (derivada de su estudio de las ketubbot de Tudela) de que esa transferencia de propiedad a la mujer mediante donación aparte podía ser una estrategia para facilitar la situación de una viuda.

En cualquier caso, se trata de una donación total de la propiedad, aunque se especifica que la mujer no podrá gestionarla hasta la desaparición del marido. A

${ }^{22}$ Una exposición sistemática de la 'donación aparte' en Lacave, Medieval Ketubbot from Sefarad, 123-131.

${ }^{23}$ Esta mattaná realizada al cónyuge es similar a otros tipos de donación como la que se puede hacer de padres a hijos, así la contenida en un documento anterior a 1462 (Apéndice a). La denominación mattaná gemurá aparece recogida en dos de las ketubbot: Jaca 1:13 y 26; 3:16, 18 y 23 (la referencia es al n. ${ }^{\circ}$ de ketubbá y a la linea de texto). 
diferencia de las ketubbot de Tudela, donde es la mujer la que está obligada a contar, en vida del marido, con su permiso para decidir acerca de la gestión de esas propiedades, en las de Jaca ( 1 y 2) son ambos cónyuges los que mutuamente se obligan y no sólo la mujer. Por otro lado, en las ketubbot de Jaca, el quinián por el que se efectúa la donación lleva la fecha al final y no al comienzo como en Tudela.

La donación de la propiedad suele incluir una serie de 'condiciones' o capitulaciones (tenaim, תנאים) que no llegan a tener la misma extensión y detalle que nos encontramos en Tudela. Estas condiciones están insertas en la mattaná, y lo mismo ocurre con una cláusula de garantía (ạ̧arayut), que queda incluida en la donación. Pero puesto que los ejemplares conservados tienen truncado el final de la parte adicional, carecemos de información acerca de la existencia de otras cláusulas como sería el 'reconocimiento' u hodaá (הודעה), expedido por el novio a nombre del que hace entrega de la dote.

Resumiendo, a día de hoy y con los materiales disponibles, las ketubbot de Jaca poseen, con ligeras variantes, la siguiente estructura:

\section{Cuerpo principal}

- Móhar ('principal' de la ketubbá; ketubbá propiamente).

- Toséfet (o ‘incremento’ de la ketubbá, adición al móhar).

- Nedunyá ('dote').

- Aḥarayut (cláusulas de 'garantía', dadas por el novio).

\section{Parte adicional}

- Mattaná ('donación') de propiedad inmueble, del novio a la novia, en forma de quinián. Contiene una serie de 'condiciones' (tenaim) y puede incluir una cláusula de 'garantía' (aharayut) de la donación.

Si entramos en el detalle del contenido de las ketubbot de Jaca en su conjunto, y a pesar de la magrez de su número, que puede ser poco representativo, se pueden extraer algunas observaciones de interés. En primer lugar, en casi todas ellas la boda se celebra en viernes (excepto Jaca 2, que lo hace en miércoles), hecho que no debe resultar llamativo, puesto que así ocurre en al menos la mitad de las ketubbot hispánicas conservadas.

Una ketubbá simboliza el punto de partida de un proyecto familiar que requiere preparativos legales que se precisa realizar relativos a la transferencia de propiedad inmueble que el novio hace a la novia. En algún caso, un año antes de la boda, como cuando en 1428 Orobuena cede a su hijo Yosef Așig la propiedad de las casas que este donaría como mattaná a su novia Oro Goyós un año des- 
pués. Aquí sorprende la antelación, que puede estar motivada por alguna razón que desconocemos. Cinco días antes de su boda en 1465, R. Iṣhac Almosnino había efectuado la donación legal a su novia Jamila ante los mismos testigos que días después estarían presentes en la firma de la ketubbá, lo que indica que las celebraciones previas de los esponsales se alternaban con actos jurídicos tendentes a preparar el marco económico de la nueva familia.

La información que nos proporcionan las ketubbot acerca de las redes sociales implicadas es importante. De manera significativa, ocho -de los diezcontrayentes de Jaca cuyo nombre conocemos pertenecen a cuatro importantes familias de la ciudad: Almosnino y Sarfatí (3 novios cada una), Goyós y Papur (2 novios cada una). Como señalaba antes, la fiabilidad de la información ofrecida por esta muestra está condicionada por su escasez, pero es significativo observar un importante nivel de endogamia en esas familias arraigadas en la ciudad, aunque carecemos de noticias relativas a la movilidad de los contrayentes por motivos matrimoniales desde otras localidades.

Uno de los aspectos que nos ofrecen las ketubbot se refieren a los bienes incluídos en ellas -su inventario y/o valoración en dinero-, tanto de la dote, como de la donación, además de las cantidades relativas al móhar y su incremento ${ }^{24}$.

Las dos dotes más importantes son las que aportan Oro Goyós en 1429 y Dueña Papur en 1489, en este último caso, a pesar de que su padre había fallecido con anterioridad. En su ketubbá, Oro recibía en concepto de incremento al principal $100 \mathrm{f}$, cantidad equivalente a la valoración de su dote. Además de ello, recibía una mattaná consistente en la propiedad de unas casas dentro de la judería de Jaca, junto a una cantidad adicional de $100 \mathrm{f}$.

De igual manera, Dueña Papur -de cuya ketubbá sólo conocemos el importe del principal, incremento y dote, aunque carecemos de información acerca de la donación hecha por el novio- aportaba al matrimonio una dote valorada en 143 f, 9 s, que doblaba la cantidad recibida (70 f) de su novio R. Šem Tob Almosnino como incremento del principal. Al compararla con el resto de las dotes resulta una cantidad ciertamente elevada, lo que hacía de Dueña un buen partido para el hijo de un cirujano judío de Jaca, al aportar un importante patrimonio.

${ }^{24}$ Las ketubbot expresan la cantidad del principal en zuzim; el incremento, dote y donación pueden aparecer expresados bien en zehubim adfonsí, nombre que designa a una moneda de oro (Jaca 1 y 5), el florín, quizás; o bien en dinerim ('sueldos') jaqueses (Jaca 2 y 4). Hago uso de las siguientes abreviaturas: f[lorín], 1[ibra], s[ueldo], d[inero], calculando en florines las cantidades expresadas en las ketubbot, según las equivalencias monetarias expuestas en P. SPuFford, Handbook of Medieval Exchange (London 1986), pág. 149 (1429, $1 \mathrm{f}=10 \mathrm{~s}, 4 \mathrm{~d} ; 1462,1 \mathrm{f}=12$ s, $4 \mathrm{~d} ; 1465,1 \mathrm{f}=13 \mathrm{~s}, 4 \mathrm{~d} ; 1487-89,1 \mathrm{f}=16 \mathrm{~s})$. 
Las cantidades reflejadas en las tres ketubbot de Raḥel Sarfatí, Jamila y Dueña Sarfatí se sitúan en un nivel más modesto. Al igual que ocurre con Dueña Papur, el padre de Rahel Sarfatí había fallecido antes de su matrimonio en 1462. En su caso conocemos únicamente el monto de la mattaná que ascendía a la mitad de unas casas en la judería de Jaca, $32 \mathrm{f} \mathrm{y} \mathrm{un} \mathrm{asiento} \mathrm{de} \mathrm{sinagoga.} \mathrm{En} \mathrm{el}$ caso de Jamila, sólo sabemos que recibía en donación de su marido R. Iṣhac Almosnino la propiedad de unas casas en la judería con la parte correspondiente de un huerto y un pozo. También en un nivel intermedio se sitúa la dote de Dueña Sarfatí, valorada en 51 f, 4 s, a lo que se suma el incremento del principal recibido, equivalente a $12 \mathrm{f}, 8 \mathrm{~d}$.

Solamente contamos con descripciones de viviendas, bastante imprecisas, en tres de las ketubbot de Jaca que conservan el apartado de la donación. Una impresión preliminar es que se trata de edificaciones de pequeñas dimensiones, con una planta baja y otra superior, orientadas en torno a patios interiores comunes que comparten con otros vecinos, con alguno de los cuales les unen relaciones de parentesco (Jaca 1 y 3): así, R. Ișhac Almosnino compartía un pozo de agua con su tío materno don Šem Tob b. R. Jacob Papur y con la viuda doña Regina (Jaca 3). Se alude a un «barrio de los judíos» (Jaca 1 y 3 ) que sería bastante homogéneo, a juzgar por los lindes mencionados, ya que en todos los casos se cita a vecinos judíos, y solo en uno aparece una mención a la «calle de los cristianos» $(\text { Jaca } 1)^{25}$.

\section{TEXTOS}

\section{Jaca $2^{26}$}

5222, elul 15 (1462, agosto 11), miércoles. Jaca

Ketubbá de matrimonio de Rahel, hija del difunto don Yehudá Sarfatí, con don Bonafós, hijo de Yosef Almosnino. El fragmento conservado incluye la parte adicional de la ketubbá, con la donación de propiedad inmueble en forma de quinián, y una cláusula de garantía (Fig. 1).

AHPH, sign. 12031, n. ${ }^{\circ} 5$

${ }^{25}$ Acompaño la transcripción de los textos con un regesto, la traducción parcial de la donación a la novia (mattaná) -puesto que el texto de la ketubbá es suficientemente conocido-, y un comentario Utilizo los siguientes símbolos: negrita = en romance en el original; [ ] = adición; $\backslash$ I = interlineado.

${ }^{26}$ Comienzo la numeración aquí, ya que la ketubbá cronológicamente anterior (Jaca 1) ya había sido objeto de edición por Lacave, art. cit. en nota 4 supra. 
[......... מקום ישיבה [....] ממוצר [...............

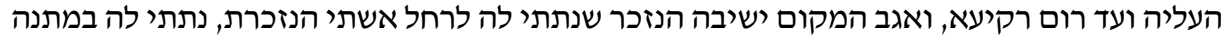

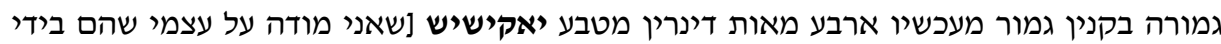

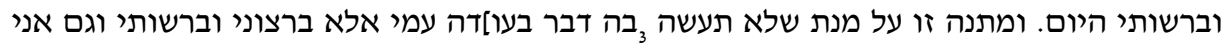

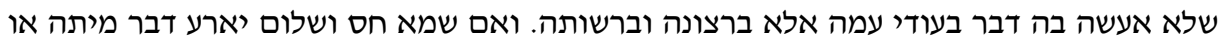

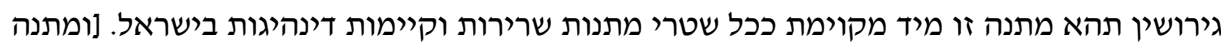

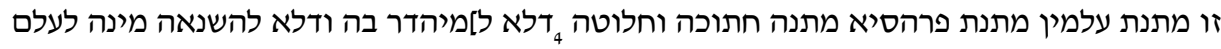

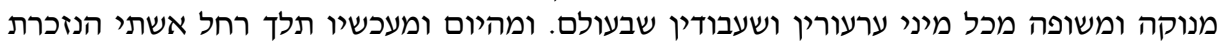

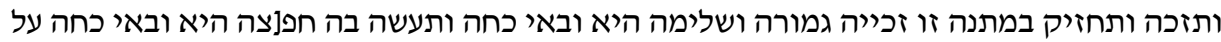

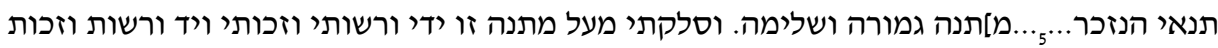

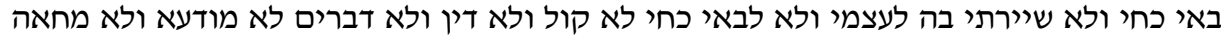

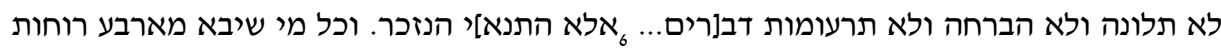

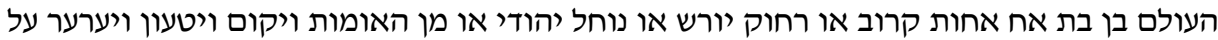

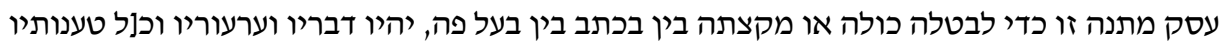

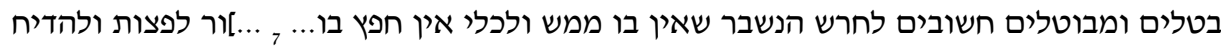

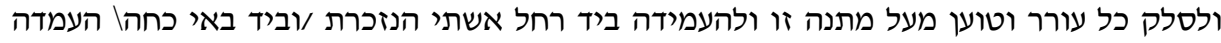

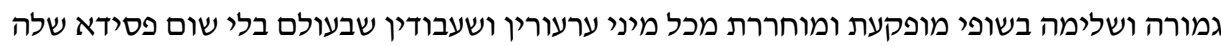

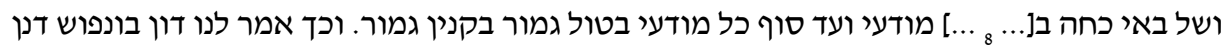

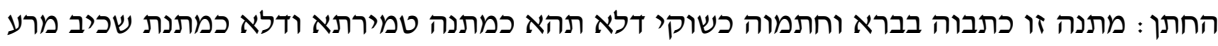

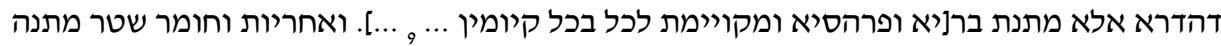

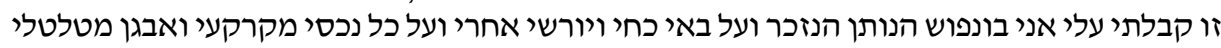

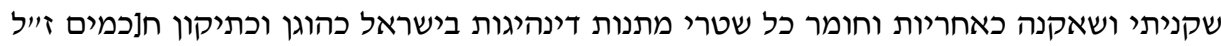

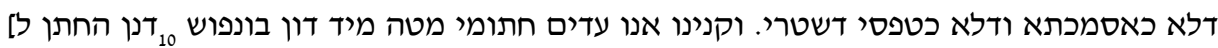

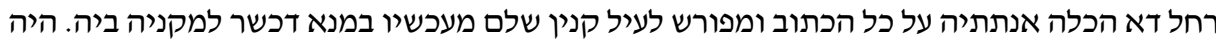

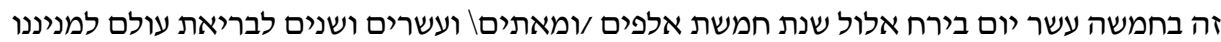

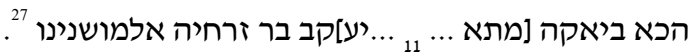

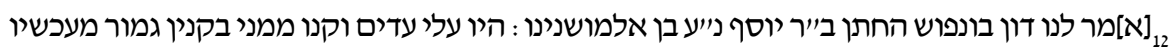

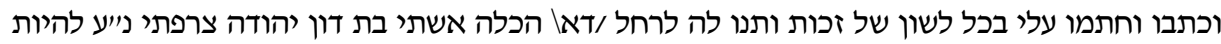

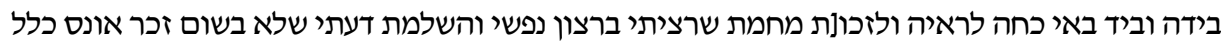

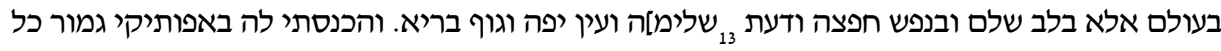

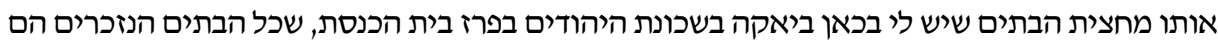

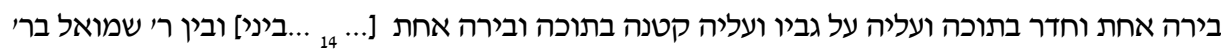

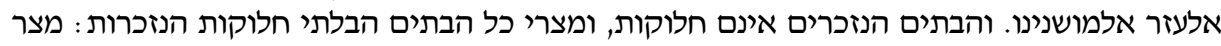

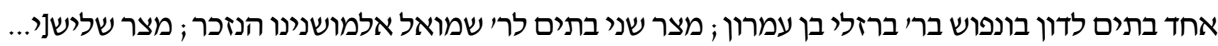

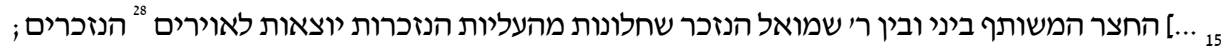

\footnotetext{
${ }^{27}$ Sigue rúbrica.

${ }^{28}$ La ketubbá de 1429 (Jaca 1) hace uso del vocablo פרזדור (1. 22), con el significado de 'corredor', aunque entre líneas añade como equivalente el término אויר aquí utilizado.
} 
ופתחי הבירות הנזכרות פתוחים לאויר החצר הנזכר. גם חלון גדול יש בבירה יוצאת לאויר דרך רשות

הרבים.

כלהמ[...

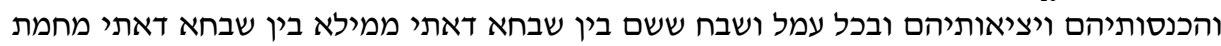

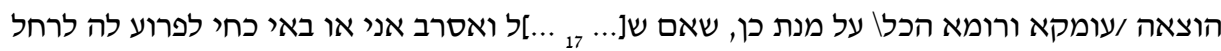

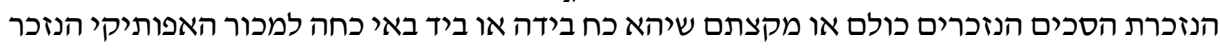

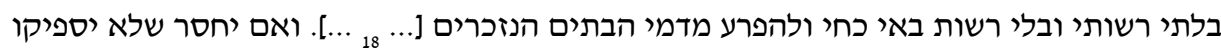

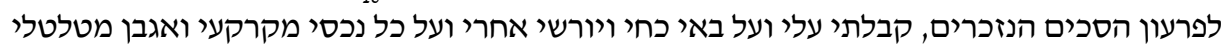

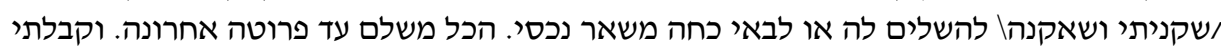

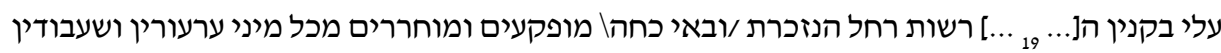

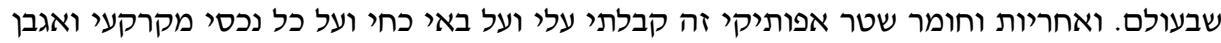

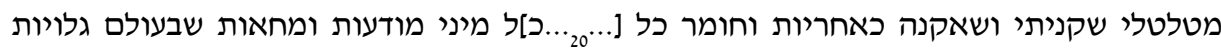

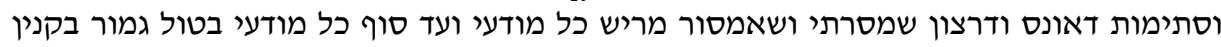

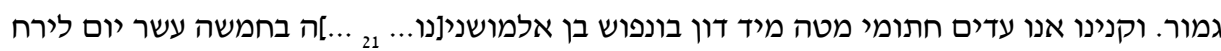

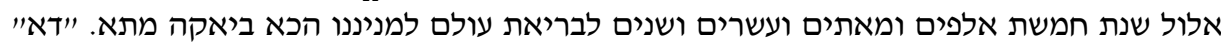

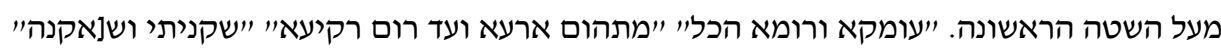

"ובאי כחה" ביני שיטי...

Traducción parcial de la donación (mattaná):

[... ] ${ }_{12}$ Nos dijo el novio don Bonafós $b$. R. Yosef, su alma descanse en el edén, $b$. Almosnino: sed mis testigos y adquirid de mí con quinián íntegro desde ahora, escribid y firmad para mí con lenguaje de derecho, y dádselo a Raḥel, \esta/ novia, mi esposa, hija de don Yehudá Sarfatí, su alma descanse en el edén, para que sirva en su mano y en mano de sus representantes de prueba y de constatación de derecho, porque quiero voluntariamente y con plena consciencia, sin ningún género de coacción en absoluto, sino de todo corazón, voluntariamente y en plena ${ }_{13}$ consciencia de buen grado y en perfecto estado de salud. Y la introduzco en propiedad plena de la mitad de las casas que tengo aquí en Jaca en el barrio de los judios en la zona de la sinagoga. Todas las casas citadas son un «palacio» con una habitación en su interior, un piso superior sobre la parte trasera y una pequeña planta alta dentro de él, y un «palacio» $\left[\ldots_{14} \ldots\right.$, entre yo] y R. Šemuel b. R. El 'azar Almosnino, aunque las casas citadas no están divididas. Los lindes de las casas citadas sin dividir [son los siguientes]: uno, las casas de don Bonafós b. R. Barzilay b. 'Amrón; segundo linde, las casas del citado R. Šemuel Almosnino; linde tercero $\left[\ldots 1{ }_{15} ..\right]$ el patio común [que hay] entre yo y el citado R. Šemuel, y las ventanas de los pisos superiores salen a los citados corredores, y las puertas de los citados «palacios» están abiertas al corredor del patio citado. También hay un mirador en el «palacio» que sale al corredor a través de una vía pública [...]. 


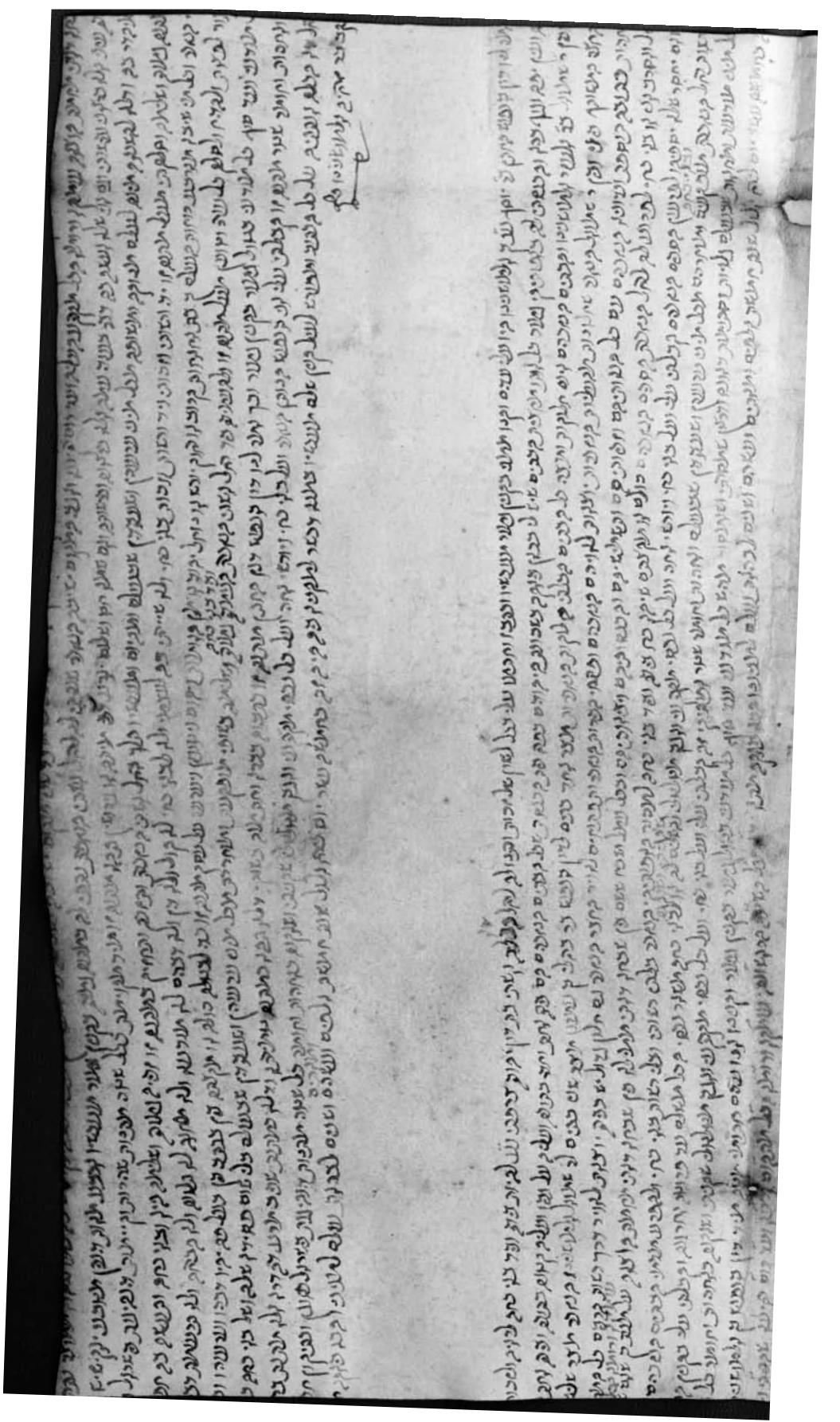

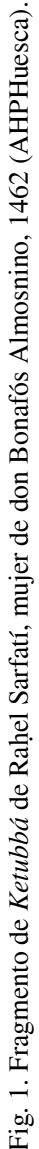


El fragmento conservado (338 x $317 \mathrm{~mm}$ ) servía de cubiertas del protocolo de Juan

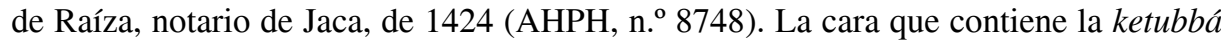
incluye en disposición perpendicular al texto hebreo tres anotaciones notariales en escritura latina fechadas el 14 de octubre 1479. Una vez reciclada la ketubbá, las anotaciones quedaron en el interior de la cubierta delantera del protocolo notarial. La datación de las entradas proporciona un límite «ante quem» para la reutilización del pergamino. La primera y la tercera anotación están en latín (y aparentemente no tienen que ver ni con la ketubbá ni con judíos); la segunda, en aragonés, registra una venta con comanda realizada por Salamón Almosnino a un cristiano. En el dorso de la ketubbá se conserva otra anotación en aragonés realizada tras quedar aquella en desuso, pues coincide con la doblez superior vuelta hacia la cara interior de la cubierta delantera. Esta doblez ocultaba la primera de las anotaciones anteriores, antecediendo a la segunda ${ }^{29}$.

El fragmento contiene parte de la sección adicional de la ketubbá y es, entre todas las ketubbot de Jaca, la más interesante en cuanto a contenido y estructura de la donación (mattaná), y su comienzo (y laterales) aparece truncado. En realidad, nos encontramos con dos donaciones separadas realizadas de manera simultánea por algún motivo que desconozco, pues la pérdida de parte del texto no permite averiguarlo.

Una primera donación (1.[íneas] 1-11) incluye la donación de un asiento (חקום) [de sinagoga] ${ }^{30}$ y de 400 s. Respecto al asiento, el fragmento conservado no nos proporciona ningún otro detalle ${ }^{31}$. La donación compromete a marido y mujer a actuar sobre los bienes donados de consentimiento mutuo. Al final, incluye una cláusula de condición y una garantía.

A continuación el mismo día, se realiza otra donación de propiedad inmueble (1. 1215) que consiste en la mitad de unas casas cuya titularidad no está dividida (sino que es compartida por Bonafós y, al parecer, R. Šemuel b. El'azar Almosnino). Esas casas comprenden un «palacio» (בירה), es decir, vivienda de una habitación, con una planta alta en la parte posterior y otra encima. Las casas se localizan en las proximidades de una de las sinagogas de Jaca, quizás la mayor, situada por Passini en la vertiente este de la Calle del Ferrenal, en las proximidades de la Calle de Cambras. Este autor logró desmentir la idea generalizada que localizaba esta sinagoga dentro del solar del antiguo Cuartel del Estudio ${ }^{32}$.

${ }^{29}$ La imagen de que dispongo no permite leer con claridad el texto de la anotación, aunque se distinguen los nombres de «Jucé Alcalá, fillo de Barzilla» y «Santó Almosnín, sanoguero».

${ }^{30}$ Tenemos noticia de que en 1481 un cristiano vende a Mossé Gastón, sastre, «hun lugar, siquiere asentadero de muger suyo en la sinoga mayor» de Jaca (Moтis, La aljama judía de Jaca, 190); obsérvese el calco realizado sobre el original hebreo.

${ }^{31}$ Una referencia documental de 1484 menciona un asiento «en la cambra clamada de las mulleres» de dicha sinagoga, cf. M. A. Motis DolADER, «Reflexiones en torno a las sinagogas de la judería de Jaca en la Edad Media», Aragón en la Edad Media X-XI (1993), págs. 641-660: 652, n. 67.

32 Passini, «La juderia de Jaca», 148. 
Después sigue una garantía de la ketubbá, incremento y dote (1. 16-17), y finalmente una segunda garantía del documento de propiedad (שטר אפותיקי) donde aparentemente se garantiza la actuación de la mujer sobre la propiedad, incluso sin el permiso de su marido (1. 18-21).

Se produce la coincidencia de que los padres de ambos novios ya no están vivos en el momento del matrimonio. Además, don Bonafós Almosnino, el novio, es el mismo que había actuado con anterioridad como testigo y escribano de una carta de donación de judíos de Sos (antes de 1462), por la que se deduce que su padre Yosef, en contraste con el momento en el que se redacta la ketubbá, aún estaba vivo. Como testigo y escribano de la parte adicional de la ketubbá, al final de la primera donación, aparece Jacob b. R. Zerahyá Almosnino. La caligrafía de su firma coincide con la de la ketubbá, y también con la del documento de procuración de 1467, reproducido más adelante.

Entre los vecinos de la vivienda objeto de donación se cita a R. Šemuel b. R. El'azar Almosnino, quizás pariente del novio, y a don Bonafós b. R. Barzilay 'Amrón (Abanbrón). De este último sabemos que es el que en 1480 y 1481 proclama «alalma e niduy» en la sinagoga de Jaca contra aquellos que incumplieran «el jurament de las usuras iuxta el fuero» ${ }^{33}$.

La reciclado de la ketubbá con anterioridad a 1479 (¡apenas 17 años después del matrimonio!) resulta, cuanto menos, extraño. A Bonafós, acerca del cual teníamos indicios de su actividad como escribano de un documento anterior a 1462, y del que ignoramos su edad en el momento de contraer matrimonio, no volvemos a encontrarlo mencionado en las noticias documentales publicadas que he podido espigar (ni siquiera, en las nóminas de prestadores). Puesto que de Raḥel Sarfatí, cuyo padre ya había fallecido al momento de casarse, desconocemos el importe de su dote y no podemos evaluar la capacidad económica de su propia familia.

La reutilización de la ketubbá, como soporte de escritura, encaja además, con algunas noticias acerca de la actividad de Johan de Pardinilla, «nuevo in fide», que se declara heredero en 1481 de los «bienes, nombres, drechos e actiones» que habían sido de un Bonafós Almosnino, y al que sucede en sus funciones ${ }^{34}$. Una consulta ordenada y directa de la documentación notarial podría quizás ayudar a resolver la interrogante abierta.

\section{Jaca 3}

5226, tebet 9 (1465, diciembre 28), viernes. Jaca

Ketubbá de matrimonio de Jamila con R. Ișhac, hijo de Jacob Almosnino. El fragmento conservado incluye algo menos de la mitad inferior del cuerpo principal, con-

\footnotetext{
${ }^{33}$ Motis Dolader, La aljama judía de Jaca, 342.

${ }^{34}$ Motis Dolader, La aljama judía de Jaca, 110, y cf. págs. 33 y 119-120.
} 
teniendo la garantía de ketubbá, incremento y dote, así como el comienzo de la parte adicional en letra cursiva con la donación de propiedad inmueble a la novia (Fig. 2).

AHPH, sign. 12031, . $^{\circ} 3$

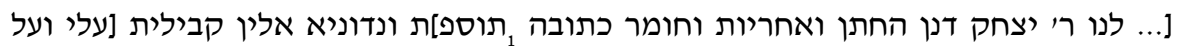

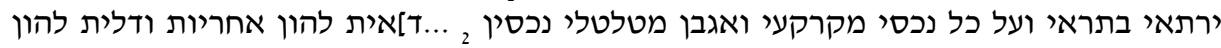

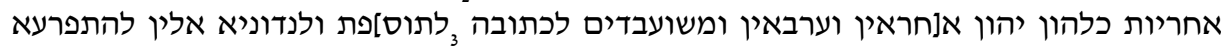

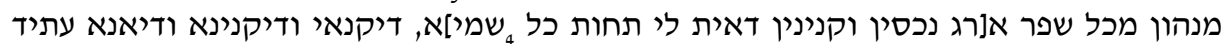

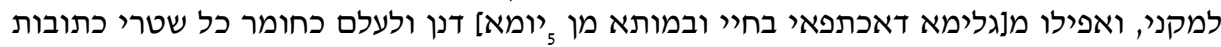

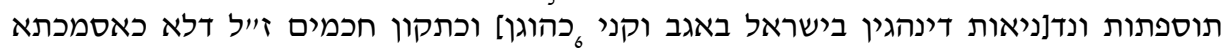

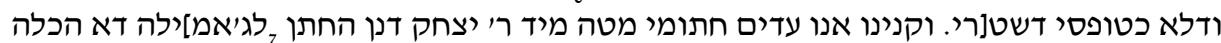

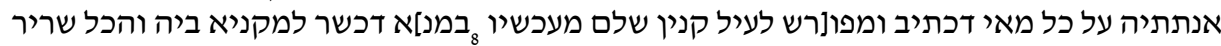

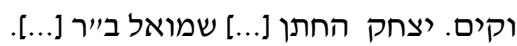

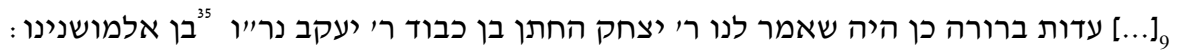

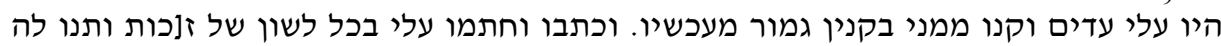
לג'מילה דא הכלא...

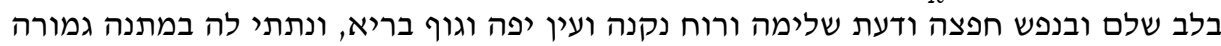
בקנינן גמור מעכשיו כל אותם הבתים ... ....

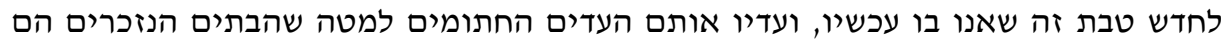
אוצר ויציא[... ל.....

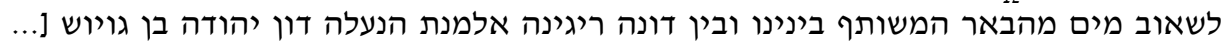

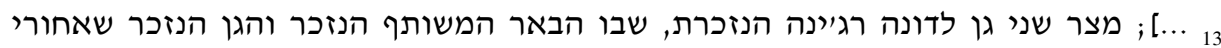

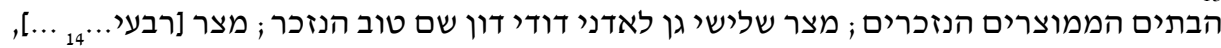

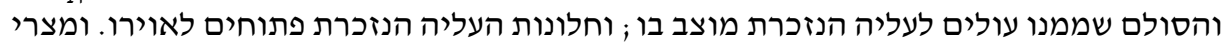

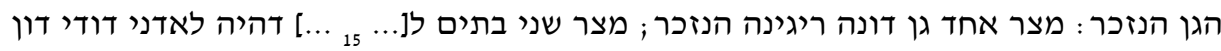

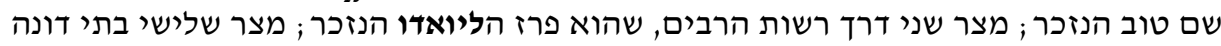

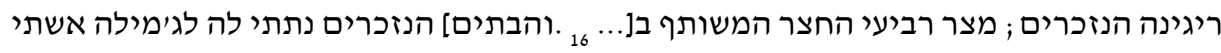

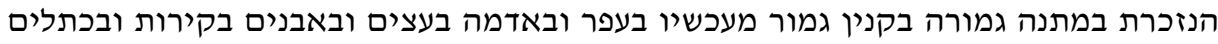
בקורות ובתקראות ומני...

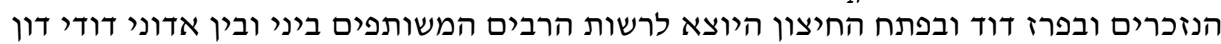
שם טוב [הנזכר...

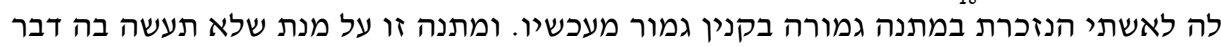

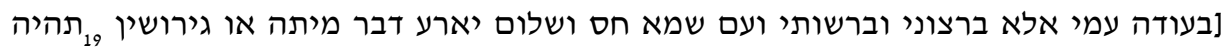

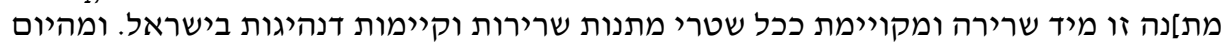

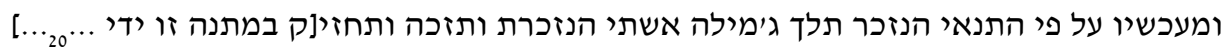

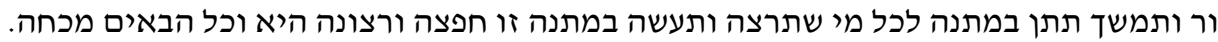

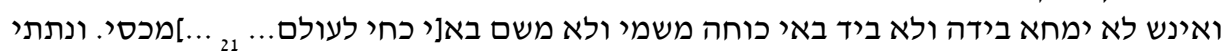

35 נר"ו : נטריה רחמנא ופרקיה ('Dios le redima y le guarde'), fórmula frecuentemente usada tras nombres de rabinos y estudiosos de la Torá. 


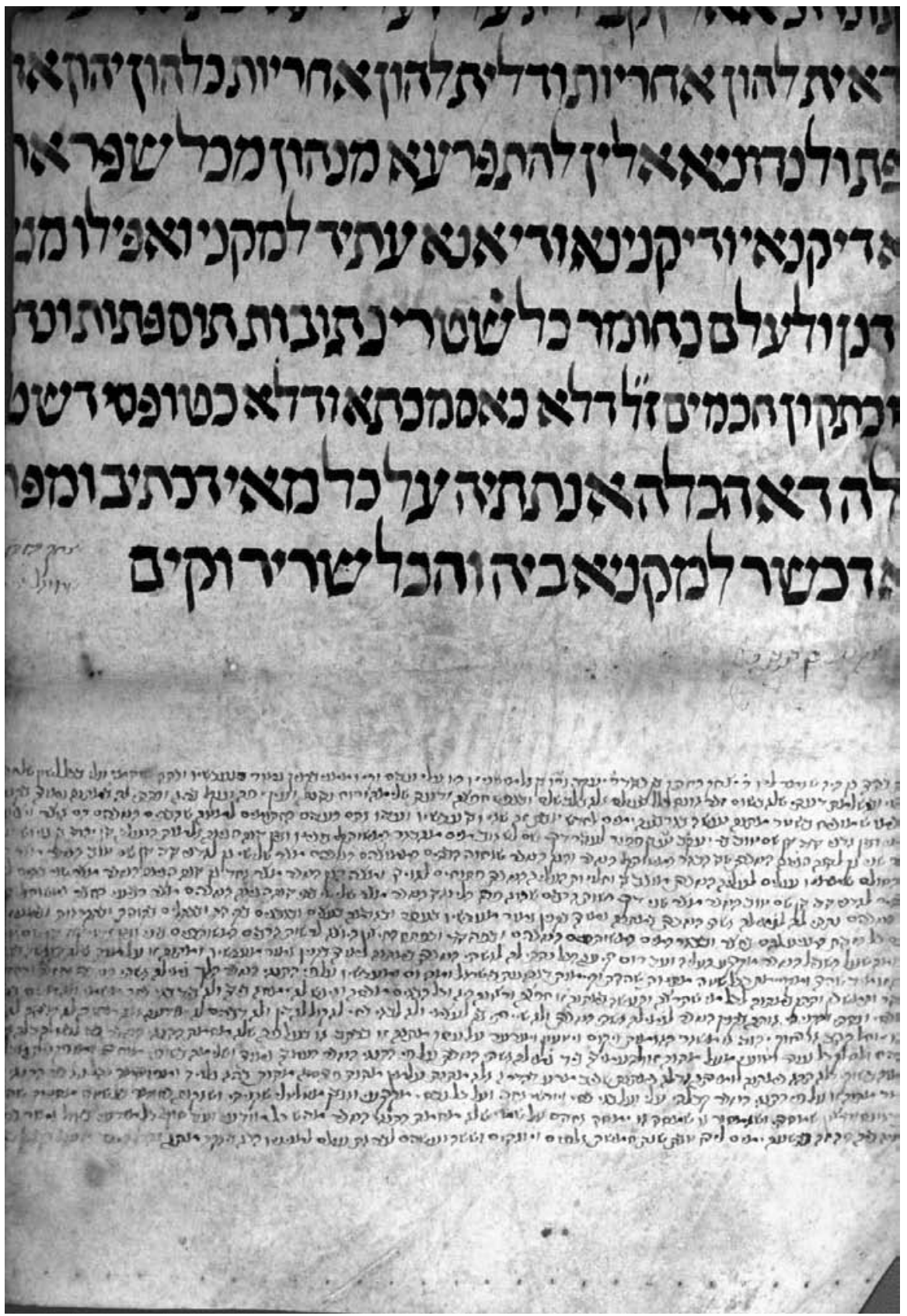

Fig. 2. Fragmento de Ketubbá de Jamila, mujer de R. Ișhạac Almosnino, 1465 (AHPHuesca). 


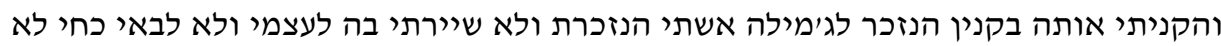

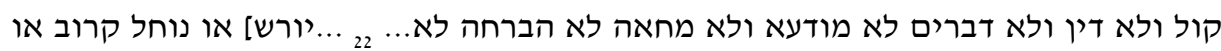

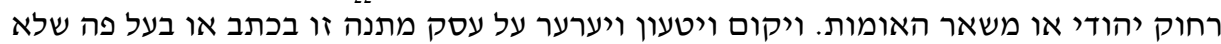

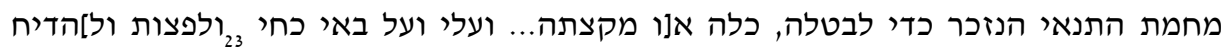

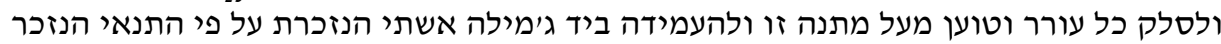

העמדה גמורה ושלימה בשופי [....

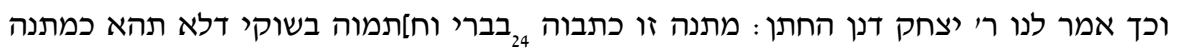

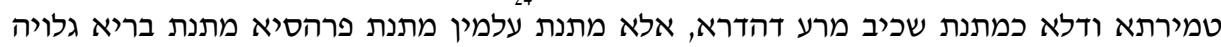

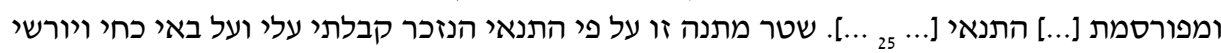

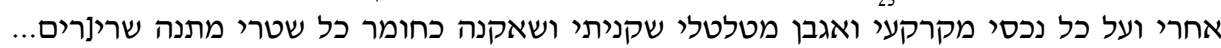

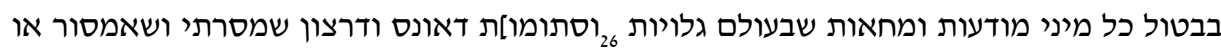

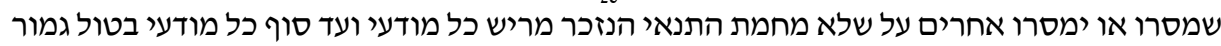

לנגמרי.

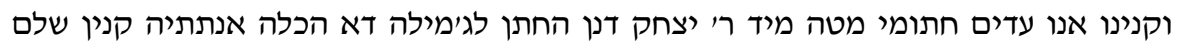

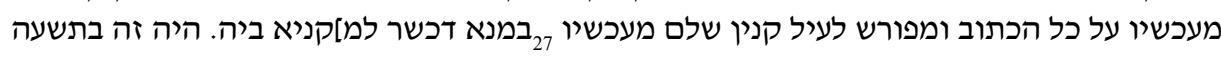

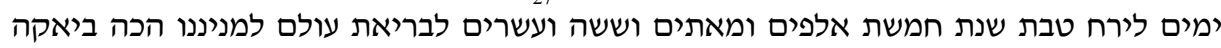

מתא

Traducción parcial de la donación:

${ }_{11}\left[\right.$...] Y las citadas casas son un ¿cillero? y $\left[\ldots_{12} . ..\right]$ entre yo y mi señor tío don Šem Tob b. R. Jacob, su alma descanse en el edén, b. Papur para pasar por alli [a fin] de extraer agua del pozo compartido entre nosotros y doña Regina, la viuda del excelso don Yehudá b. Goyós [... $\left.{ }_{13} . ..\right]$; linde segundo, el huerto de la citada doña Regina, en el cual está el pozo compartido, y el huerto citado que está detrás de las mencionadas casas delimitadas; tercer linde, un huerto de mi señor tío, el citado don Šem Tob; linde [cuarto... ${ }_{14}$... ]; y la escalera, a través de la cual se sube a la planta superior citada, se ubica allí, y las ventanas de la planta superior están abiertas a su corredor. Y los límites del citado huerto [son]: uno, el huerto mencionado de doña Regina; segundo linde, casas de [... $\left.{ }_{15} . ..\right]$ que era de mi señor tío, el citado don Šem Tob; segundo linde [sic], la vía pública, que es la citada zona del levado; tercer linde, las citadas casas de doña Regina; cuarto linde, el huerto compartido con [... ${ }_{16}$ ... Y las casas] citadas se las doy a Jamila, mi mujer mencionada, mediante donación íntegra con un quinián completo desde ahora con el polvo y la tierra, la madera y las piedras de los muros, y con las paredes, las travesañas y los techos y $\left[\ldots_{17} ..\right]$ con todo el derecho que les corresponde, con el huerto y el pozo de agua citados compartidos y con la zona de $i ?{ }^{37} y$ la puerta exterior que sale a la vía pública, compartidos entre yo y mi señor tío don Šem Tob [citado.... ....], y lo que hay sobre el sendero citado, desde el suelo de la planta superior hasta las alturas del cielo. Todo se lo doy a mi mujer citada mediante donación íntegra [...]

\footnotetext{
${ }^{36}$ Siguen varias signaturas ilegibles.

${ }^{37}$ La lectura del texto hebreo es clara (דוד), no así su significado ('zona de ¿David/tío?').
} 
El fragmento de pergamino (327 x $224 \mathrm{~mm}$ ) servía de cubiertas del protocolo de Juan de Javierre, notario de Jaca, de 1495 (AHPH, n. ${ }^{\circ} 8713$ ) ${ }^{38}$, aunque carezco de detalles que me permitan aventurar una fecha aproximada de reutilización de la ketubbá. Sufre recortes laterales y se observan perforaciones de cosido en la parte inferior.

Una de las singularidades de esta ketubbá es el hecho de que la mattaná ('donación') había tenido lugar cinco días antes de los esponsales, el lunes 4 de tebet ( 23 de diciembre 1465), inmediatamente después de Janucá, en presencia de los mismos testigos de la ketubbá, y para ello remite a un documento aparte.

La estructura de la parte adicional es más sencilla que la del anterior ejemplar: comienza con la garantía que da el novio de pago de ketubbá, incremento y dote y a la que añade su firma (1. 1-8). A continuación se incluye la donación, en forma de quinián (l. 9-18), que tuvo lugar días antes, y finalmente, una serie de condiciones finales referentes a la donación (1. 18-23).

Podemos identificar al novio R. Ișhac b. Jacob Almosnino con el hijo del escribano que redacta la ketubbá de 1462, que, además, es el mismo que redacta en 1467 la carta de procuración que recibe David Maçó de Jaca (Apéndice b). Ișhac aparece firmando otra ketubbá años más tarde (Jaca 5). Podría fácilmente identificarse con el R. Açach Almosnin, citado repetidamente en el ejercicio de diversos cargos de la aljama -entre ellos, el de escribano- a fines de la década de 1470 y comienzos de la siguiente $^{39}$. En cuanto a su tío materno, Šem Tob b. Jacob b. Papur, no es segura su identificación con el «Sentó Papur» incluido en una nómina de 1479 de judíos dedicados al crédito ${ }^{40}$. De Jamila, desconocemos la familia de la que procedía, así como el importe de su dote. La reutilización de la ketubbá abre algún interrogante acerca de la posición de la familia, o de, al menos, alguno de sus miembros, en 1492.

Los recortes laterales impiden conocer con exactitud la composición exacta de la donación que Iș̣̣ac Almosnino realiza a Jamila, que incluye el acceso compartido con su tío al pozo de agua de doña Regina, la viuda de don Yehudá Abengoyós. No he logrado localizar las casas y huerto trasero situadas junto a la propiedad de su tío materno, ni tampoco identificar el área en donde se sitúan (פרז הליואדו, 'zona del levado').

${ }^{38}$ Reproducciones parciales de esta ketubbá aparecieron en la cubierta del libro de Motis Dolader, La aljama judía de Jaca, y en Aragón Sefarad. Vol. II. Exposición y catálogo. El legado judio en Aragón (Zaragoza 2004), págs. 242-243.

${ }^{39}$ Motis Dolader, La aljama judía de Jaca, 119, 342, etc.

${ }^{40}$ Motis Dolader, La aljama judía de Jaca, 342. 


\section{Jaca 4}

5248, tebet 14 (1487, diciembre 29), viernes. Jaca

Ketubbá de matrimonio de Dueña, hija de R. Šem Tob Sarfatí con R. Yehudá, hijo de R. Yosef Sarfatí. Se conserva sólo el cuerpo principal de la ketubbá, con detalle del principal, incremento y dote, así como su cláusula de garantía (Fig. 3).

AHPH, sign. 12031, . $^{\circ} 8$

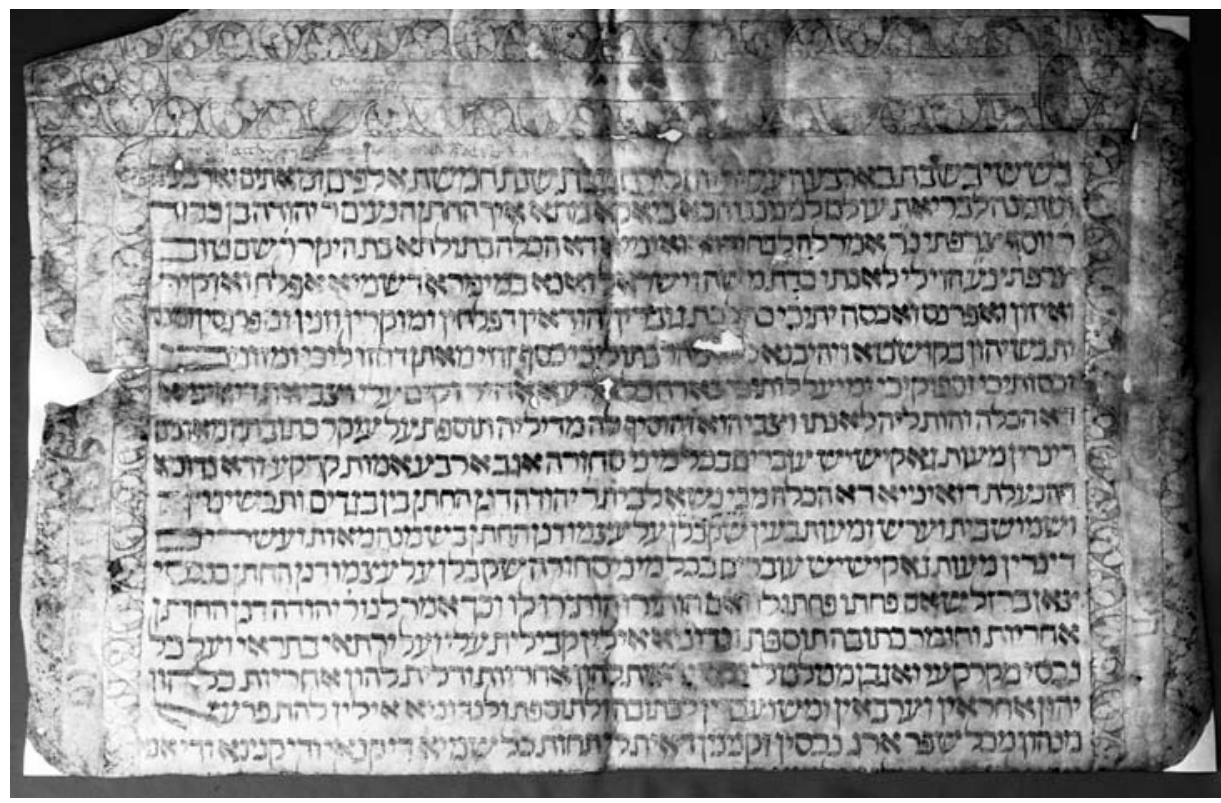

Fig. 3. Fragmento de Ketubbá de Dueña Sarfatí, mujer de R. Yehudá Sarfatí, 1487 (AHPHuesca).

בששי בשבת בארבעה עשר יום לירח טבת שנת חמשת אלפים ומאתים וארבעים ושים ושמונה

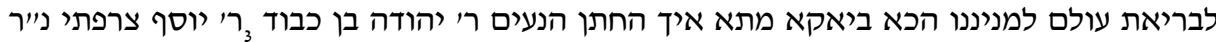

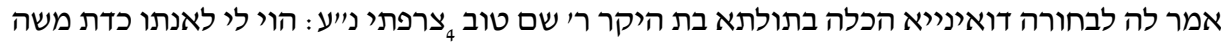

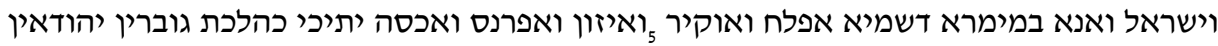

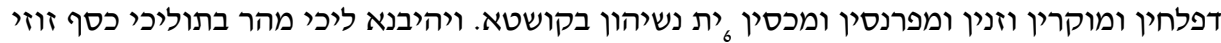

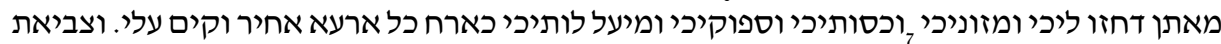

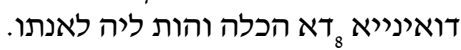
וצבי הוא והוסיף לה מדיליה תוספת על עיקר כתובתה מאתים ,דינרינרין מעות ג׳אקישישיש עוברים בכל מיני סחורה אגב ארבע אמות קרקע.

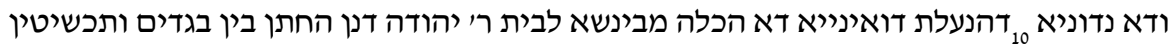

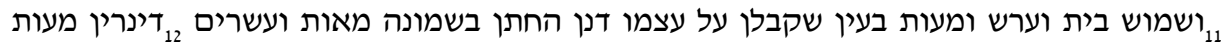




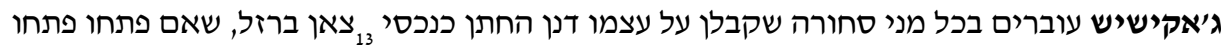

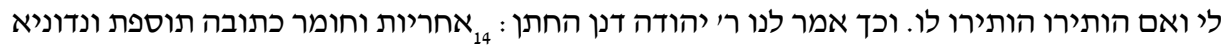

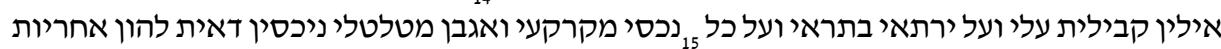

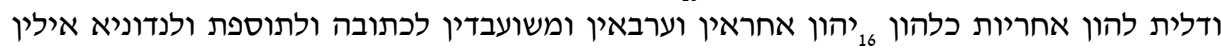

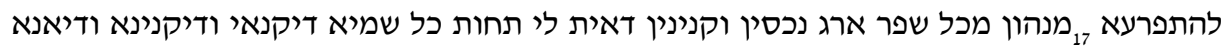

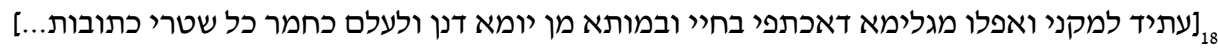

El fragmento conservado $(316$ x $485 \mathrm{~mm})$ servía de cubiertas del protocolo de Antonio de Larraz, notario de Berdún, de 1544 (AHPH, n. ${ }^{\circ}$ 7074) ${ }^{41}$. Contiene el cuerpo principal de la ketubbá. El recorte del pergamino eliminó las firmas de los testigos y escribano, por lo que resulta difícil conocer su identidad.

La ketubbá aparece adornada por una orla doble con motivos florales en tonalidades verde y roja. La franja central entre ambas orlas adornadas contiene un texto en el cual se puede distinguir [...] לבניך שלום correspondiente al final del salmo 128:6 que trata de la felicidad familiar, pero el resto se ha borrado. Hay que recordar que otro versículo del mismo salmo había sido utilizado en la decoración de la ketubbá de 1429.

Los contrayentes comparten «apellido», al igual que Rahel, la novia de la ketubbá de 1462 (Jaca 2). De Dueña Sarfatí sabemos que aporta al matrimonio una dote que sin ser muy alta, tampoco es desdeñable (valorada en $51 \mathrm{f}, 4 \mathrm{~s}$, o bien $820 \mathrm{~s}$ ). El padre de Yehudá, el novio, cabe identificarlo con el Jucé Çarfatí que aparece repetidamente mencionado en nóminas de asistentes en la sinagoga al juramento de observancia de la legislación de «usuras» en 1479 y en varios años sucesivos ${ }^{42}$.

\section{Jaca 5}

5250 , tebet 4 (1489, noviembre 28), viernes. Jaca

Ketubbá de matrimonio de Dueña, hija del difunto R. Hanane[l] Papur con R. Šem Tob, hijo de maestre Astruc Almosnino, cirujano. Conserva todo el cuerpo principal de la ketubbá con detalle del principal, incremento y dote, así como su cláusula de garantía (Fig. 4).

AHPH, sign. 12031, n. ${ }^{\circ} 7$

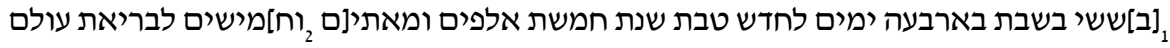

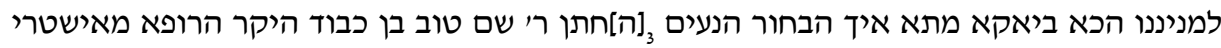

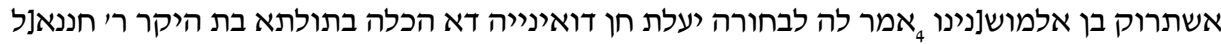

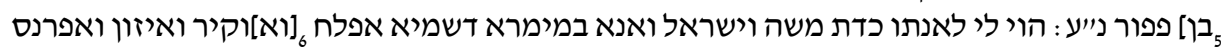

\footnotetext{
${ }^{41}$ Reproducido en Aragón Sefarad. Vol. II, pág. 247.

${ }^{42}$ Motis Dolader, La aljama judía de Jaca, 342-344 y 346-347.
} 
ואכסה יתיכי כהלכת גוברין יהודאין דפלחין ומוקרין וזנ]ין וממיפרנסין ומכסין ית נשיהון בקושטא.

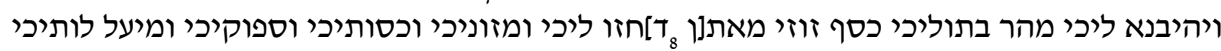

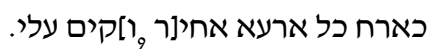

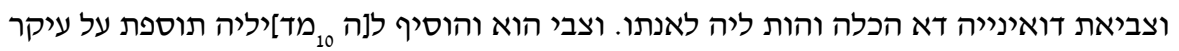
כתובתה שבעים זהובים יפים וטובים שקולים אדפונש]יא

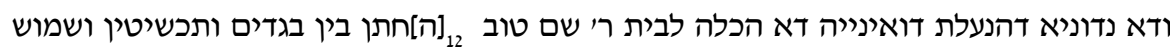

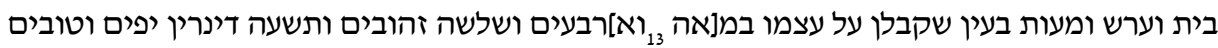

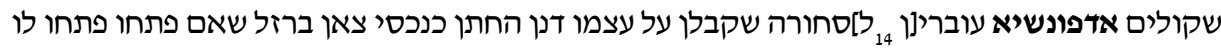
ואם [הותירו הוזיתירו לו. וכן אמר לנו ר' שם טוב דנן החתן : אחריות וחומר כתובה תוספת ונדוניא

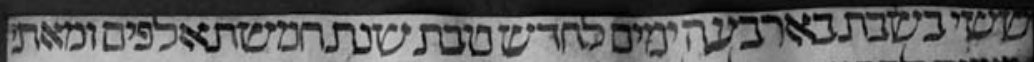
| 19

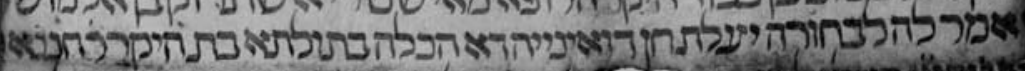
Tפes 的

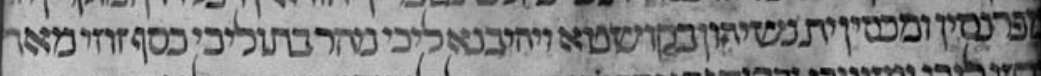

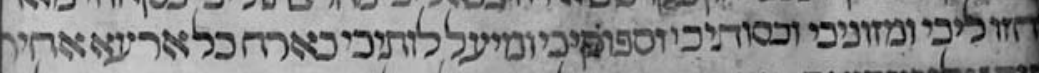

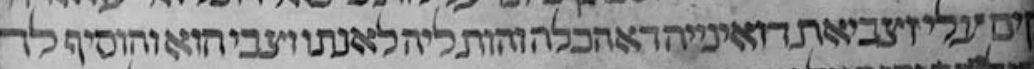

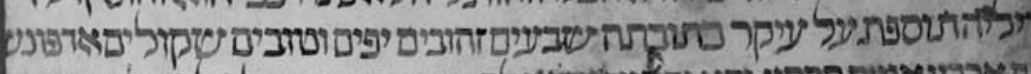
ו

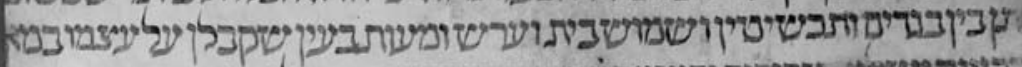

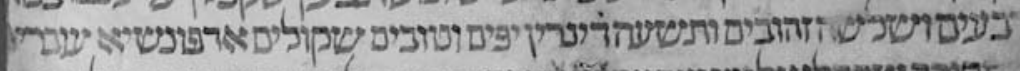
ט. *

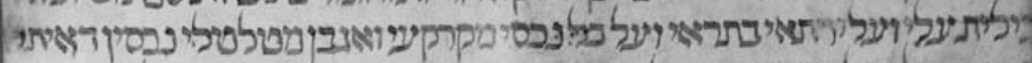

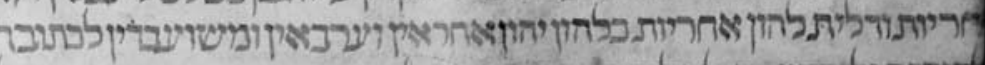
קט

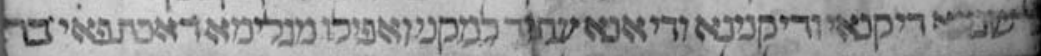

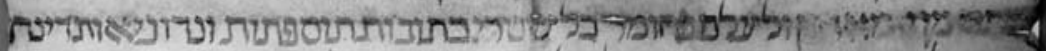

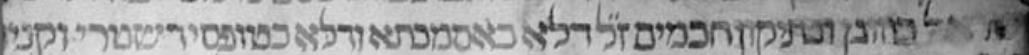

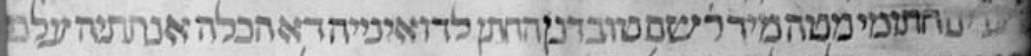
ה

Fig. 4. Fragmento de Ketubbá de Dueña Papur, mujer de R. Šem Tob Almosnino, 1489 (AHPHuesca). 


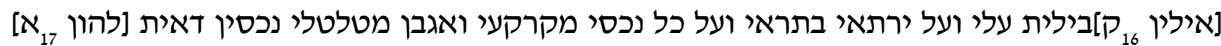

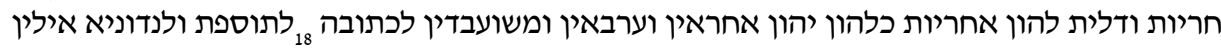

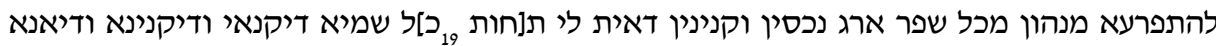

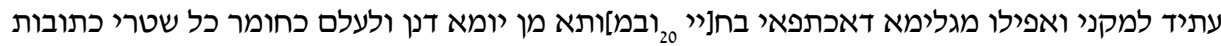

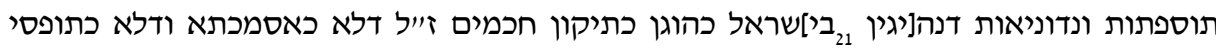

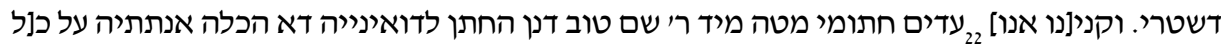
מאי]

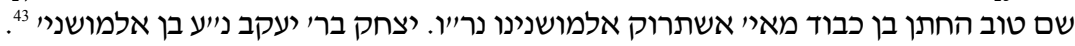

El fragmento (397 x $359 \mathrm{~mm}$ ) servía de cubiertas del protocolo de Martín de Lasala de 1493-1495 (AHPH, n. ${ }^{\circ}$ 7767), y conserva, a pesar de los recortes laterales, todo el cuerpo principal de la ketubbá. Incluye al dorso, una anotación hebrea en escritura cursiva: כתובת דואיניאה אשת שם טוב אלמוסנינו ('ketubbá de Dueña, mujer de Šem Tob Almosnino'), que pone de relieve el hecho de que la ketubbá está en posesión de la mujer (o de sus herederos).

Las familias de los contrayentes (Almosnino y Papur) aparecen vinculadas por otras relaciones de parentesco: de hecho, uno de los testigos de la ketubbá, R. Ișhac b. Jacob Almosnino, estaba vinculado por via materna a los Papur (podemos identificar su firma con la del novio homónimo de la ketubbá de 1465 [Jaca 3]).

El padre del novio, el cirujano maestre Astruc Almosnino, aparece frecuentemente mencionado en la documentación notarial de Jaca: así lo encontramos en diversas nóminas de judíos que realizan el juramento anual relativo al cumplimiento de la legislación relativa a las «usuras». Además, es mencionado como responsable de la aljama de Jaca en 1489 como uno de sus adelantados ${ }^{44}$. Su actividad médica y vida privada han dejado también huella, siquiera somera, en la documentación notarial: si la noticia ha sido correctamente interpretada, Šem Tob, el novio, sería hijo de un primer matrimonio de maestre Astruc. Este habría tenido en el mismo matrimonio otros tres hijos varones, al menos, de los cuales el cirujano actúa como tutor y curador en $1487^{45}$. Por esa razón, se puede entender que Dueña, la novia, que aporta una valiosa dote valorada en $143 \mathrm{f} \mathrm{y} 9 \mathrm{~d}$ resultaba un buen partido para uno de sus hijos.

Si comparamos el valor de la dote con otras ketubbot, la cantidad resulta bastante elevada, y no podemos olvidar que el padre de la novia ya había fallecido. Respecto a

${ }^{43}$ Sigue una rúbrica.

${ }^{44}$ Motis Dolader, La aljama judía de Jaca, 342-344 y 346-347; y 155, respectivamente.

${ }^{45}$ Acerca de su actividad médica, cf. Motis Dolader, La aljama judía de Jaca, 136. La información concerniente a su situación familiar aparece recogida en una referencia a la adquisición de ciertas casas, cf. ibíd., 203. 
Hananel Papur, éste se puede identificar con «Faranel Papur», citado en alguna nómina de judíos que juran guardar las regulaciones relativas a la «usura» ${ }^{46}$. La ketubbá incluye, además, un incremento de $70 \mathrm{f}$ aportados por el novio, aunque desconocemos la cantidad a la que ascendía la donación de bienes inmuebles.

\section{Epílogo}

La aridez del formulismo textual de las ketubbot deja entrever algunos datos preciosos que, contrastados con otras fuentes, arrojan algo de luz acerca del matrimonio judío y de los perfiles de sus contrayentes en una localidad aragonesa. Los textos nos permiten penetrar más allá de los nombres de alguna de estas judías de Jaca que reciben sus ketubbot en el siglo XV: Oro Goyós, Rahel Sarfatí, Jamila, Dueña Sarfatí, Dueña Papur. Podemos así interpretar las dotes que aportan al matrimonio y los bienes que reciben en donación, y hallar indicios adicionales acerca de su recorrido vital posterior.

La ketubbá es el registro documental de un importante momento de las vidas de estas mujeres, como lo es para sus parejas y familias, y su estudio nos obliga a intentar nuevas vías de investigación, enfocando tanto al grupo (comunidad o familia), como al individuo. En el primero de los casos, los documentos arrojan una, aunque escasa, valiosa información prosopográfica, fundamental para trazar un mapa, todavía en sus inicios, de redes sociales a nivel local y regional. Por otro lado, permiten descubrir las identidades de alguno de los oficiales de la comunidad, en este caso, los escribanos.

A nivel individual, se hace necesario ir más allá de una lectura plana del documento, por sí sola importante si se hace con rigor, y plantearse nuevos interrogantes. Es preciso enfocar la ketubbá y, en consecuencia, el enlace matrimonial, como un punto de partida. Sin perder de vista la perspectiva textual, convendría enfocar la atención sobre determinados detalles materiales y anotaciones posteriores, indicios, en suma, que trascienden lo textual. No en vano, el peculiar modo de conservación de estas ketubbot recicladas en cubiertas, puede servir de metáfora cruel de unos destinos no destruidos, pero sí truncados, de mutaciones de identidad que recubren formas de ser que ya no se toleraron más. Es una línea que merecería la pena seguir explorando en alguno de los casos, como el de Rahel Sarfatí (casada en 1462), y quizás también los de Dueña Sarfatí (casada en 1487) y Dueña Papur (casada en 1489). De una manera u otra, el proyecto de vida iniciado entonces, y simbolizado en sus respectivas ketubbot, quedó truncado.

${ }^{46}$ Motis Dolader, La aljama judía de Jaca, 342-343. Aparece citado en 1479-80, pero no en las nóminas de años sucesivos. 


\section{Apéndice}

Aunque sin relación aparente con las ketubbot anteriores, los dos documentos cuyo texto hebreo ofrezco a continuación, tienen la particularidad de haber sido redactados por dos escribanos de Jaca de la familia Almosnino mencionados en dichas ketubbot. En concreto, Bonafós, b. Yosef Almosnino, escribano de la carta de donación (a) efectuada por unos judíos de Sos, es el novio que otorga la ketubbá de 1462. A su vez, Jacob b. Zerahyá Almosnino, escribano de (al menos) la parte adicional de esa misma ketubbá, es también escribano de la carta de procuración de 1467 (b) otorgada en Jaca. De ambos documentos dio reproducción fotográfica Cabezudo Astraín en su estudio acerca de (la expulsión de) los judíos de Sos, aunque sin añadir dato alguno del primero de los documentos. Del segundo sí dio una traducción bastante aproximada que le proporcionó J. L. Lacave.

a

Antes de 1462. Sos

Carta de donación de Ester con su marido Yosef Gualid a su hija Oro y su marido Yosef, judios de Sos. Bonafós Almosnino de Jaca aparece como testigo (Fig. 5).

Archivo Histórico de Protocolos [= AHP], Sos del Rey Católico, prot. Juan Ramírez 1499.

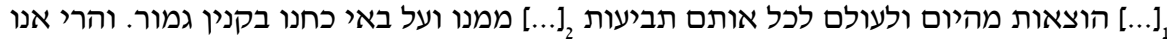

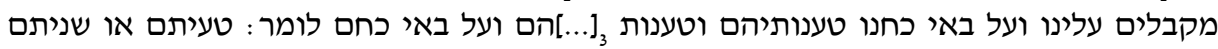

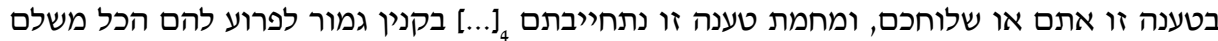

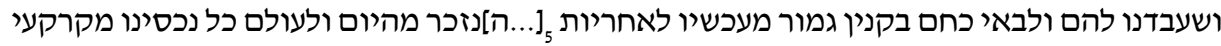

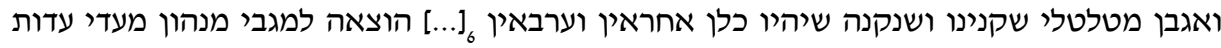

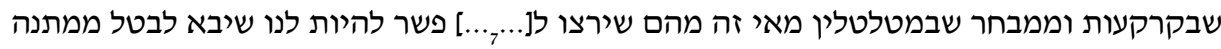

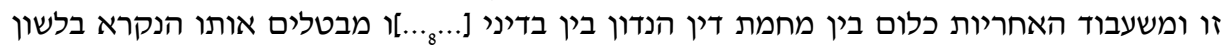

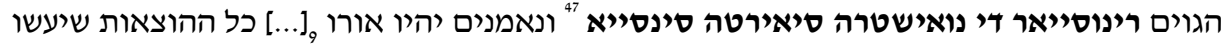

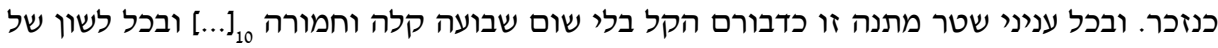

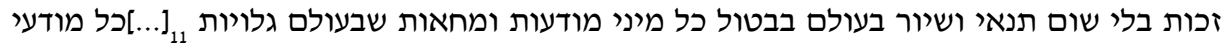

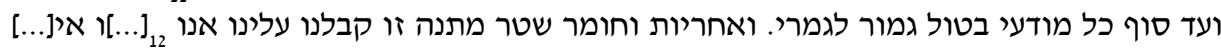

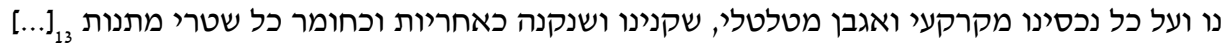

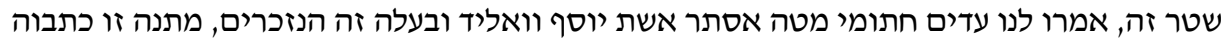

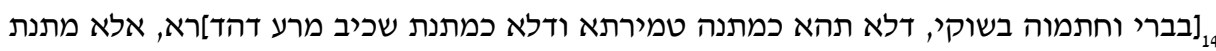

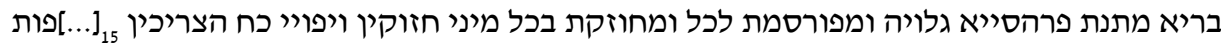

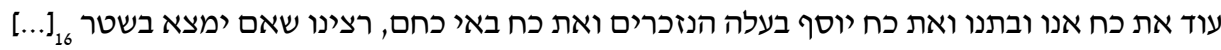

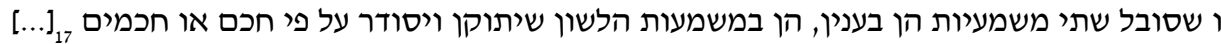

\footnotetext{
${ }^{47}$ Alj. «Renu[n]çiar de nuestra çierta çençia».
} 


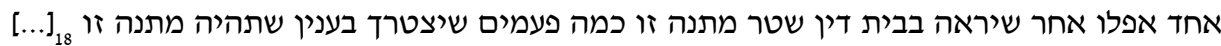

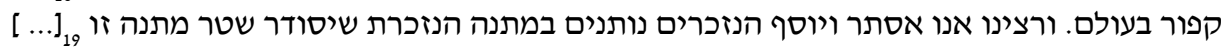

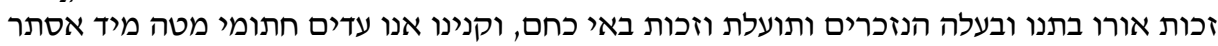

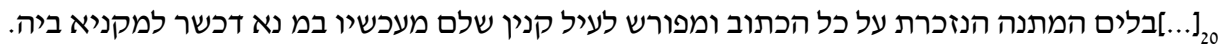

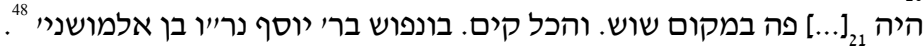

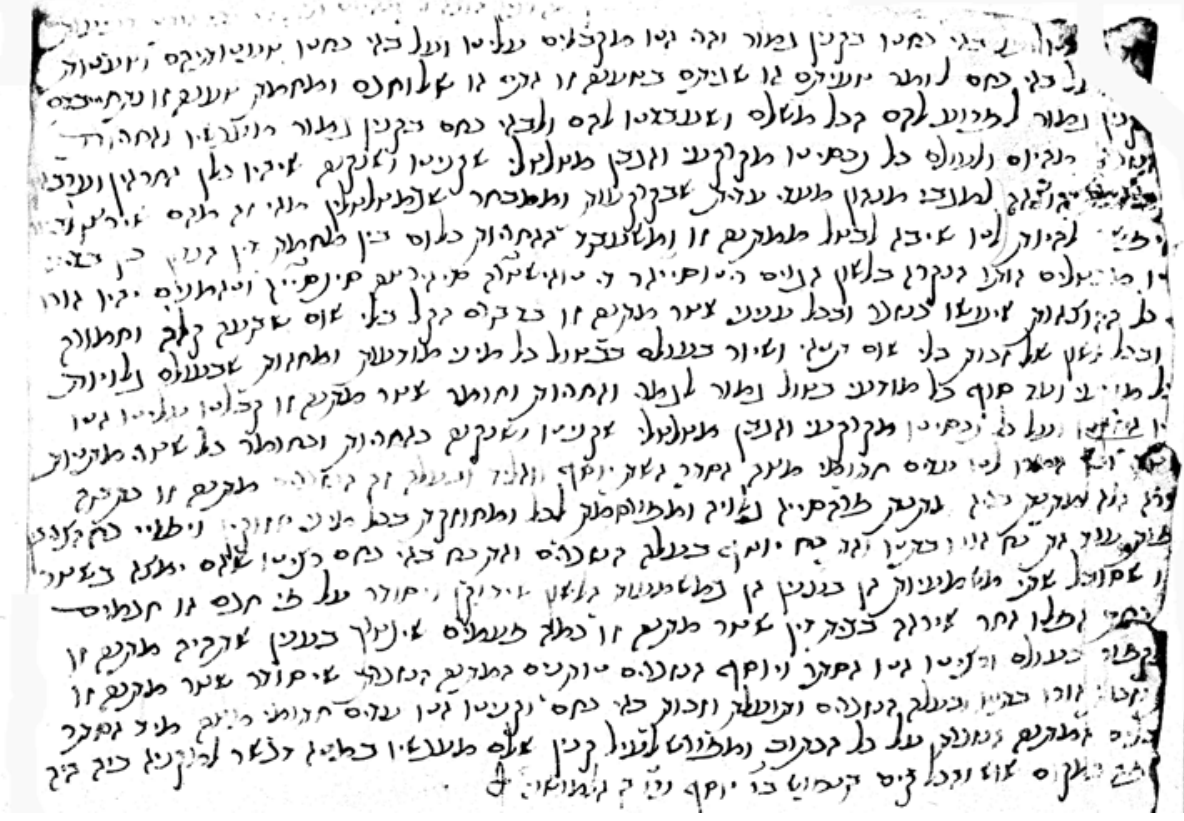

Fig. 5. Carta de donación de Ester y Yosef Gualid para su hija Oro y su yerno, antes de 1462 (AHP, Sos).

El fragmento del documento en pergamino envolvía un protocolo notarial de Juan Ramírez, notario de Sádaba (1499). Una imagen del original fue reproducida (sin transcripción, resumen, ni regesto) en el estudio de Cabezudo Astraín sobre la expulsión de los judíos de Sos ${ }^{49}$. La parte conservada del texto no nos permite conocer el alcance de la donación. Como es usual en este tipo de documentos, el nombre de la mujer precede al de su marido. Aquí, los donantes mencionan una cláusula de renuncia de sus derechos, «llamada en la lengua de los cristianos renu[n]ciar de nuestra çierta çençia». El resto del fragmento no contiene ningún otro dato de interés histórico. Aunque la donación está datada en Sos, el escribano es Bonafós Almosnino de Jaca, el mismo cuya

\footnotetext{
${ }^{48}$ Sigue rúbrica.

49 J. Cabezudo Astraín, «La judería de Sos del Rey Católico», Sef 32 (1972), págs. 89-104: 97.
} 
ketubbá se redacta en 1462. El documento en cuestión es anterior a esta, puesto que al momento de realizar la donación, Yosef, el padre de Bonafós, aún estaba vivo. Años después, en 1467, encontramos a Jucé Gualid como testigo en una escritura notarial ${ }^{50}$. Algún miembro de la familia Gualid había tenido en el pasado una posición destacada en esta aljama ${ }^{51}$. En contraste con Jaca, caracterizada en las ketubbot como «matá» ('ciudad'), Sos recibe el apelativo de «maqom» ('lugar').

b

5227, šebat 27 (1467, febrero 2), lunes. Jaca

Carta de autorización y apoderamiento (procura $o$ שטר הרשאה) otorgado por el joven Hayyim Alcast[i]el a su cuñado David Maçó, de Jaca, ante Jacob (hijo del difunto R. Zerahyá) Almosnino y Bonafós Elnieto, ambos de Jaca, para recibir los bienes de su padre Gentó Alcastiel que habían sido consignados a Mošé de Ruesta y Mošé Bivag, adelantados de la aljama de Sos (Fig. 6).

AHP, Sos del Rey Católico, prot. Martín de Ampiedes, 1467

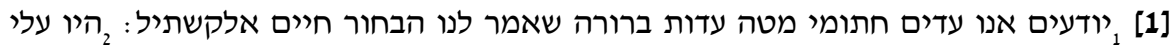

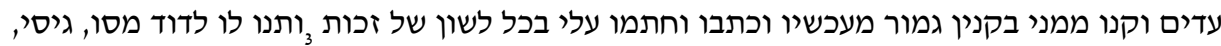

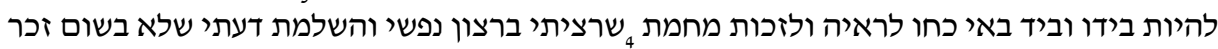

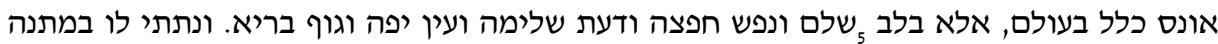

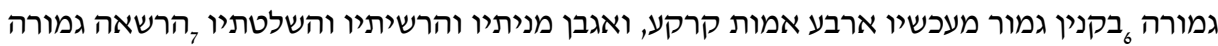

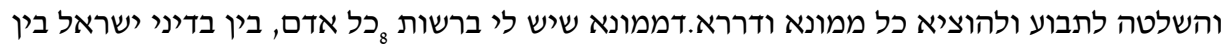

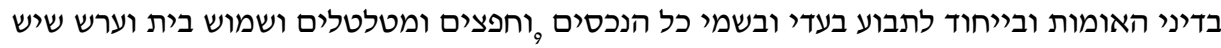

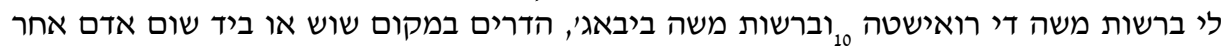

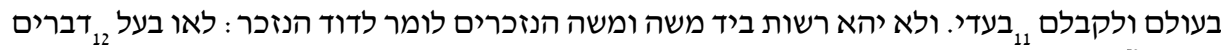

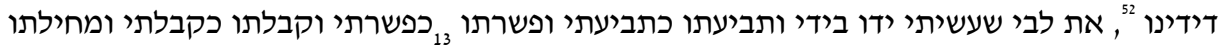

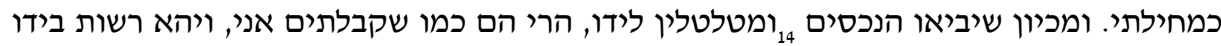

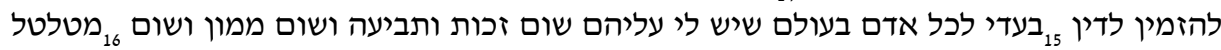

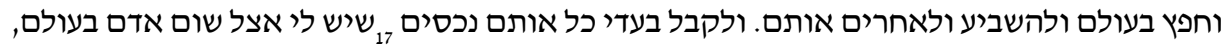

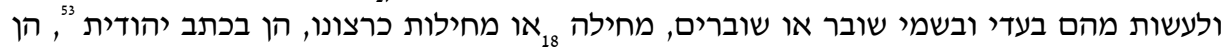

${ }^{50}$ Cabezudo Astraín, «La judería de Sos», 102.

${ }^{51}$ David, hijo de Mossé Gualit, era adelantado de la aljama de Sos ca. 1310-13, cf. F. BAER, Die Juden im Christlichen Spanien. I. Urkunden und Regesten. Bd. 1. Aragonien und Navarra (Berlin 1929), doc. 163, pág. 199.

${ }^{52}$ bKetubbot $92 \mathrm{~b}$.

${ }^{53}$ Sic. 


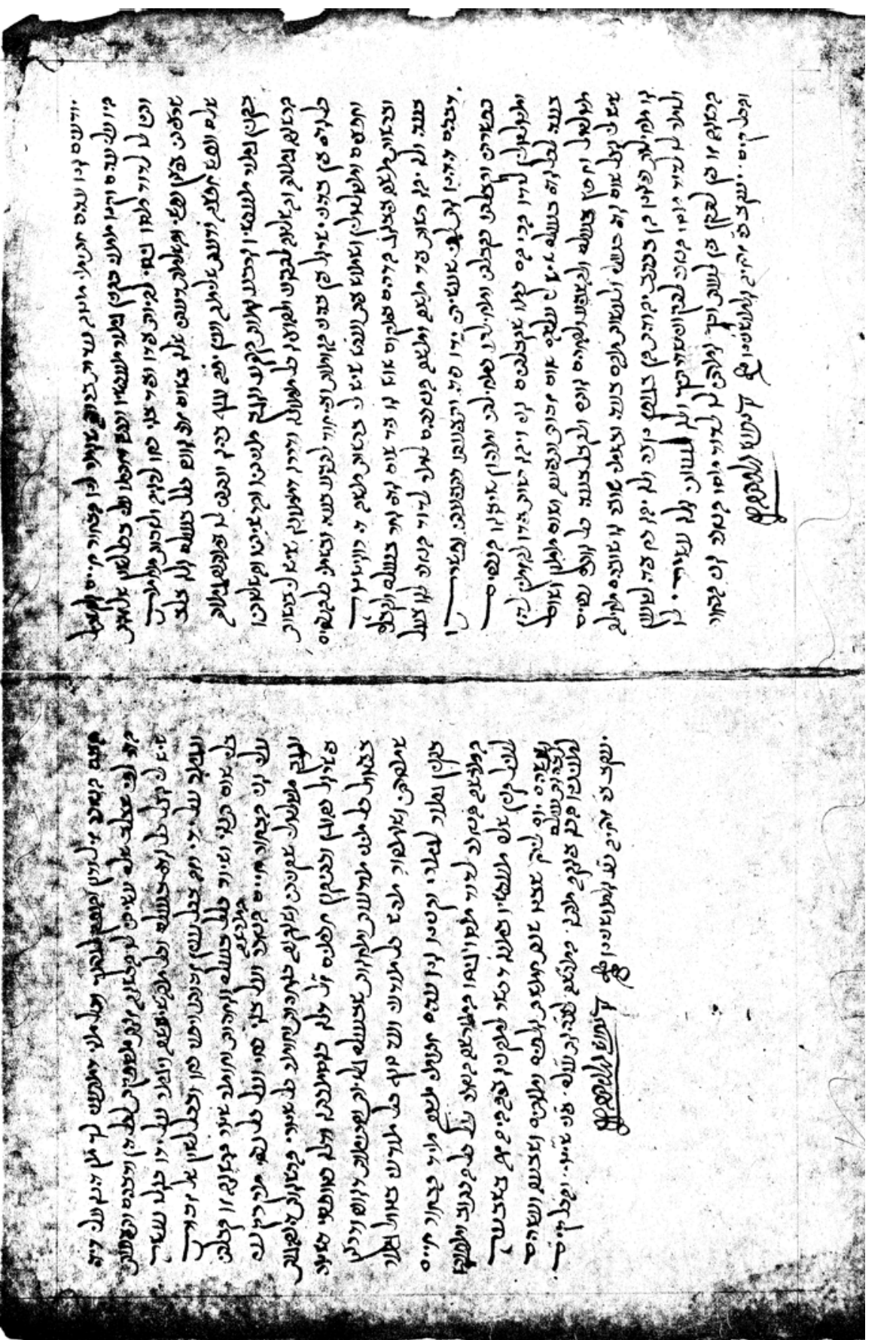

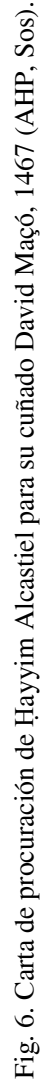




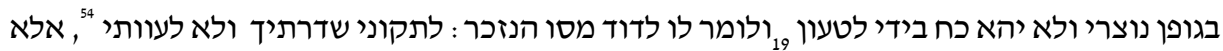

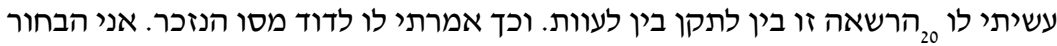

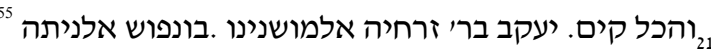

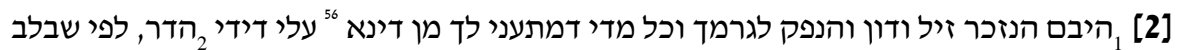

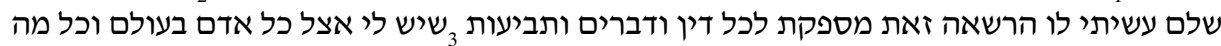

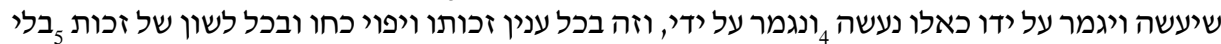

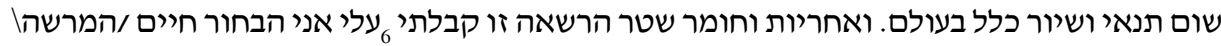

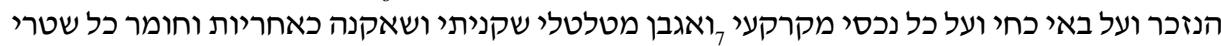

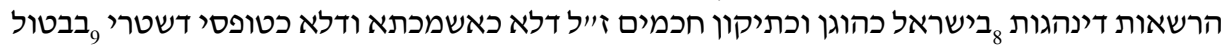

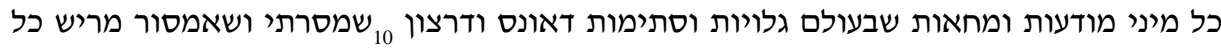

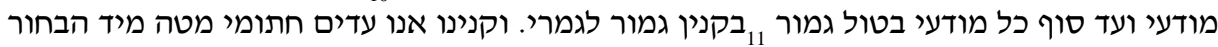

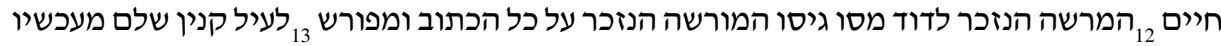

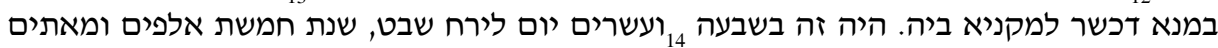

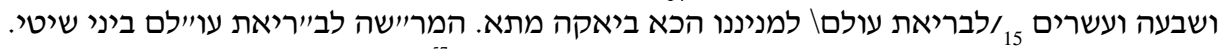

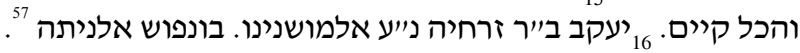

A diferencia de los fragmentos anteriores, este documento no apareció en las cubiertas de un protocolo, sino acompañando una escritura notarial: consiste en dos carillas de papel (198 x $146 \mathrm{~mm}$ ) que contienen la autorización concedida en Jaca por el joven Hayyim Alcast[i]el a su cuñado David Maçó de Jaca para tomar posesión de los bienes que, a la muerte de su padre Gentó Alcast[i]el, habían quedado consignados a los adelantados de la aljama de Sos, por ser entonces Hayyim menor de edad. Uno de esos adelantados, Mošé Bivag (que es citado junto con Mošé de Ruesta), puede ser el mismo que en 1492 tenía una casa enfrente del hospital de los judíos de Sos ${ }^{58}$.

El miércoles 11 de febrero, diez días después del apoderamiento en Jaca, David Maçó otorgaba albarán en Sos, tras haber recibido los bienes de su difunto suegro, y así quedaba registrado ante un notario de la localidad que había recibido el documento hebreo de "procura» (AHP, Sos del Rey Católico, prot. Martín de Ampiedes, 11 de febrero 1467) ${ }^{59}$. Entre los testigos del albarán se menciona a Jucé Gualit, posiblemen-

${ }^{54} \mathrm{bKetubbot} 85 \mathrm{a}$.

${ }^{55}$ Sigue rúbrica detrás de ambos nombres, y lo mismo en la otra carilla.

${ }^{56} \mathrm{~b} B Q 71 \mathrm{a}$.

${ }^{57}$ Una traducción fiable del texto realizada por J. L. Lacave, aunque no la transcripción hebrea, aparece recogida en CABEzudo Astraín, «La judería de Sos», 103-104. En términos generales sigue siendo válida.

${ }^{58}$ Cabezudo Astraín, «La judería de Sos», 97.

${ }^{59}$ Cabezudo Astraín, «La judería de Sos», que da la fecha de 1466. Puede tratarse de un error, ya que la datación del texto hebreo (1467) es clara. 
te el mismo que, con su mujer Ester, otorga antes de 1462 la carta de donación a su hija y yerno.

Un análisis en paralelo de la información que proporcionan los documentos hebreo y romance (2 y 11 de febrero 1467, respectivamente) revela diferencias significativas ${ }^{60}$. Los bienes de Gentó Alcast[i]el habían sido consignados a su muerte a los adelantados de la aljama, al ser entonces Hayyim menor de edad. En consecuencia, es posible que hubiera pasado ya algún tiempo desde el fallecimiento de Gentó, y Hayyim ya no era menor, pues de lo contrario resulta difícil creer que hubiera podido apoderar a su cuñado ${ }^{61}$. Un problema adicional que plantea el documento notarial (a partir de la descripción de Cabezudo) son las diferencias de la onomástica de los protagonistas, aunque la lectura del documento hebreo no deja lugar a dudas.

El albarán romance contenido en protocolo notarial señala a Jacob Almosnino como escribano de la aljama de Jaca, y su papel como «testificador» de la «procura». De manera paralela, el documento hebreo aparece firmado al pie de las dos carillas por Jacob Almosnino y Bonafós Eln[i]eta.

Recibido: $25 / 10 / 2006$

Aceptado: 07/02/2007

${ }^{60} \mathrm{Me}$ ha sido imposible acceder directamente al protocolo notarial, y por ello, utilizo, con alguna precaución, la información proporcionada por Cabezudo.

${ }^{61}$ Varios individuos de la familia Alcastiel aparecen documentados en localidades circundantes: Lérida 1353 (BAER, Die Juden. Bd. I. Aragonien, n. ${ }^{\circ}$ 250, pág. 345); Huesca 1364 (ibíd., pág. 386) y Tudela 1480 (ketubbá de Buena, hija de Iṣhac Alcastiel). 